\title{
Optimal foraging and community structure: implications for a guild of generalist grassland herbivores
}

\author{
G.E. Belovsky \\ The University of Michigan School of Natural Resources Ann Arbor, MI 48109-1115, USA
}

\begin{abstract}
Summary. A particular linear programming model is constructed to predict the diets of each of 14 species of generalist herbivores at the National Bison Range, Montana. The herbivores have body masses ranging over seven orders of magnitude and belonging to two major taxa: insects and mammals. The linear programming model has three feeding constraints: digestive capacity, feeding time and energy requirements. A foraging strategy that maximizes daily energy intake agrees very well with the observed diets. Body size appears to be an underlying determinant of the foraging parameters leading to diet selection. Species that possess digestive capacity and feeding time constraints which approach each other in magnitude have the most generalized diets. The degree that the linear programming models change their diet predictions with a given percent change in parameter values (sensitivity) may reflect the observed ability of the species to vary their diets. In particular, the species which show the most diet variability are those whose diets tend to be balanced between monocots and dicots. The community-ecological parameters of herbivore body-size ranges and species number can possibly be related to foraging behavior.
\end{abstract}

Key words: Optimal foraging - Herbivory - Grass lands - Body size - Competition

Optimal foraging ecology (Schoener 1971; Pyke et al. 1977) has been widely applied in the study of autecology (Krebs and Davies 1978; Rapport and Turner 1975, 1977). However, it has been little used in addressing problems dealing with the study of higher order ecological relationships such as competition, predation and trophic dynamics (Brown 1981). The exception has been the use of foraging strategies in studying competition (Werner 1977; Belovsky 1984a). Nonetheless, an analysis of foraging behavior for the majority of members of a single trophic level within a community and how this might relate to community structure has not appeared in the literature.

This paper examines the foraging ecology of 14 herbivorous species at the National Bison Range, Montana. These species range in body mass over seven orders of magnitude $\left(2 \times 10^{-4}-6 \times 10^{2} \mathrm{~kg}\right)$, include members of two very different classes (Insecta and Mammalia) and four orders (Orthoptera, Rodentia, Lagomorpha, Artiodactyla), and account for over $90 \%$ of the herbivore biomass and plant consumption in the community. Using these species, a series of questions was addressed:

1) Can the diets of all 14 species be accounted for by a single model?

2) Do all the species have the same foraging strategy [i.e., time-minimizing or energy-maximizing sensu Schoener (1969); Hixon (1982)]?

3) How does body mass influence the importance of different foraging parameters?

4) Can the range of body sizes and number of species of herbivores in a community be explained by foraging considerations?

Belovsky $(1978,1984$ b, c) has shown that the optimization technique of linear programming can explain diet selection by three herbivores (moose: Alces alces, snowshoe hare: Lepus americanus, beaver: Castor canadensis). Furthermore, linear programming techniques have been shown (Belovsky 1984d) to be biologically and mathematically most appropriate for modelling herbivore foraging. This technique enables the inclusion of constraints operating on the forager's feeding choices that arise from their physiology, anatomy or behavioral repertoire. Foods that are patchily rather than randomly or uniformly distributed can be easily handled in the model. Finally, linear constraint values can be determined in a non-circular fashion; this is far more difficult to accomplish if constraints are nonlinear. Furthermore, the solution for non-linear constraints requires the use of non-linear programming techniques, which are more complicated.

The linear programming model of herbivore foraging (Belovsky 1978, 1984b, c, d) is composed of four feeding constraint equations which reflect limits on the animal's foraging and its ability to achieve different foraging goals. These equations are characterized by:

1) digestive capacity and its fill by different food plants,

2) daily foraging time and its utilization by the cropping of different food plants,

3) daily energy requirements and their fulfillment by energy provided by different food plants, and

4) daily nutrient requirements and their satisfaction by the nutrient contents of different food plants.

With the above constraints, linear programming can be used to predict diets that maximize or minimize various goals. The two most commonly examined goals are either the achievement of greatest daily energy intake (energy maximizer) or satisfaction of minimum energy requirements in the least feeding time (time minimizer). A time minimizer 
presumably achieves the greatest fitness by spending its time in other activities than feeding (e.g. mating, caring for young, hiding from predators, etc.) after it satisfies some minimal nutritional need. An energy maximizer presumably achieves the greatest fitness by ingesting the greatest amount of energy or other nutrients. In addition, a forager might seek to minimize filling its digestive tract and still satisfy minimal nutritional requirements, since a full digestive tract is mass that must be transported and may reduce the forager's ability to run away from predators. The importance of these alternate feeding goals or strategies has been presented elsewhere (Schoener 1969, 1971, 1983; Pyke et al. 1977; Belovsky 1984d; Hixon 1982).

\section{Study site}

The necessary data to construct linear programming models of herbivore foraging were collected during the summers (May-Sept.) of 1978-1982 at the National Bison Range, Montana. The Bison Range is an intermountain Palouse prairie ranging in elevation from 800 to $1,600 \mathrm{~m}$ above sea level. The area, although overgrazed in the past (pre-1960's) by bison (Bison bison), is today maintained to represent the original vegetation and is perhaps undergrazed. The vegetation is dominated by monocots ( $70 \%$ by biomass), with forbs and woody plants (dicots) comprising $20 \%$ and $10 \%$ by biomass, respectively (Belovsky unpubl. data). The common monocots are Agropyron spicatum, Festuca idahoensis, Festuca scabrella, Koeleria cristata and Poa pratensis. Common forbs are Lupinus sp., Achillea sp., Balsamorrhiza sagitata, Penstemmon sp., Arnica soraria, and Tragopogon dubious, while common woody plants are Artemisia frigida, A. ludoviciana, A. dracunoloides and Symphoricarpos occidentalis. Over the Bison Range, the average plant biomass of new growth is $189 \mathrm{~g} / \mathrm{m}^{2}$ (s.e. $=22.1, n=40$ ) (Belovsky unpubl. data).

\section{Methods and model parameters}

The vegetation. Belovsky $(1978,1984$ d) points out that the linear programming model predicts diet choices between plants which differ in their impact on foraging constraints and which are spatially located in separate patches (i.e., they cannot be searched for simultaneously). On the Bison Range in summer, plants appear to fall into two classes, monocots (predominantly graminoids) and dicots (forbs and deciduous leaves), based upon their nutritional value, digestive capacity utilization and distribution in the environment.

Nutritional characteristics were estimated by digesting $0.5 \mathrm{~g}$ dried samples (10 samples/species) of vegetation in $\mathrm{HCl}$ and pepsin, an approximate measure of digestibility for herbivores (Terry and Tilley 1964). Digestive capacity utilization was measured as bulk (wet wt/dry wt) for 10 samples/species. For these plant traits, monocots were far more similar to each other than to forbs or deciduous leaves, while forbs and deciduous leaves were very similar to each other (ANOVA, Table 1). Therefore, monocots were considered one food plant class, while dicots (forbs and deciduous leaves) were considered another.

Distribution of monocots and dicots in the environment was determined by sampling at 10 sites $(0.16 \mathrm{ha})$ reflecting different slopes, aspects and elevation at the Bison Range. Sixteen to $400.01 \mathrm{~m}^{2}$ plots were located randomly at each
Table 1. Comparison of the characteristics of different plant growth forms as foods for herbivores using ANOVA

\begin{tabular}{|c|c|c|c|}
\hline & $\begin{array}{l}\text { Sample } \\
\text { Size }\end{array}$ & $\overline{\mathrm{x}} \pm$ S.D. & $\begin{array}{l}\text { F-value } \\
\text { with } \\
\text { categories } \\
\text { above }\end{array}$ \\
\hline \multicolumn{4}{|c|}{ Food Bulk (wet wt/dry wt): } \\
\hline Grasses & 16 & $1.64 \pm 0.35$ & \\
\hline $\begin{array}{l}\text { Forbs: } \\
\text { Herbs } \\
\text { Deciduous leaves }\end{array}$ & $\begin{array}{l}23 \\
16\end{array}$ & $\begin{array}{l}2.70 \pm 0.75 \\
2.63 \pm 0.42\end{array}$ & $\begin{array}{l}38.46^{* * *} \\
41.10^{* * *} \\
0.11^{\mathrm{a}}\end{array}$ \\
\hline
\end{tabular}

Food Digestibility ( $\%$ dry matter soluble in acid + pepsin):

\begin{tabular}{lccr} 
Grasses & 21 & $21.17 \pm 5.42$ & \\
Forbs: & & & \\
Herbs & 30 & $42.05 \pm 10.25$ & $74.17^{* * *}$ \\
Deciduous leaves & 17 & $48.06 \pm 10.25$ & $107.81^{* * *}$, \\
& & & $3.90^{\mathrm{a}}$ \\
\hline
\end{tabular}

a N.S.; $* * P<0.05 ; * * * P<0.001$

Table 2. Data on the distribution of grasses and forbs at 10 sites at the National Bison Range, Montana. A one-sided test was used because a negative association and positive skewness were hypothesized, i.e., monocots and dicots are patchily distributed in different portions of the environment

\begin{tabular}{rllll}
\hline \multirow{2}{*}{ Site } & $n$ & \multicolumn{2}{l}{ Skewness coefficient } & $\begin{array}{l}\text { Spearman Rank } \\
\text { correlation }\end{array}$ \\
\cline { 3 - 4 } & & Grass & Forb & \\
\hline 1 & 40 & $2.58^{* *}$ & $3.20^{* *}$ & $-0.33^{* *}$ \\
2 & 36 & $0.54^{*}$ & $3.28^{* *}$ & $-0.59^{* *}$ \\
3 & 40 & 0.16 & $1.05^{* *}$ & $-0.26^{* *}$ \\
4 & 30 & $2.65^{* *}$ & $3.05^{* *}$ & -0.10 \\
5 & 40 & $1.59^{* *}$ & $2.65^{* *}$ & -0.01 \\
6 & 18 & $1.01^{*}$ & $1.57^{* *}$ & -0.27 \\
7 & 18 & -0.57 & $1.05^{* *}$ & $-0.34^{*}$ \\
8 & 16 & 0.71 & $2.79^{* *}$ & $-0.36^{*}$ \\
9 & 16 & $1.07^{* *}$ & $1.14^{* *}$ & $-0.32^{*}$ \\
10 & 16 & 0.12 & $1.60^{* *}$ & $-0.50^{*}$ \\
\hline
\end{tabular}

* $P<0.10$, one-sided; ** $P<0.05$, one sided

site; the vegetation was clipped, separated to monocot and dicot, dried, and weighed. Skewness coefficients for the distribution of monocot and dicot biomasses at each site were computed; a positive coefficient indicates a "patchy" distribution within each food class (Table 2). Spearman Rank correlations were computed for the association of monocot and dicot abundances at each site to determine whether monocots and dicots occur together (Table 2). For monocots, $9 / 10$ sites had positive skewness coefficients (binomial probability: $P<0.001)$ and $6 / 10$ areas were statistically significant $(P<0.10)$. For dicots, $10 / 10$ sites had significant positive skewness coefficients, (binomial probability: $P<$ 0.001 ). These results indicate that dicots are strongly distributed in patches, while monocots are less so but still not randomly or uniformly distributed. Furthermore, 10/10 sites had a negative rank correlation between monocots and dicots (binomial probability: $P<0.001$ ), and for $7 / 10$ sites the association was significant $(P<0.10)$. Therefore, monocots and dicots are distributed patchily and their 
patches do not occur together, requiring non-simultaneous search by herbivores if they are to feed on both.

The foragers. Model parameters reflecting the consumption of monocot and dicot foods were collected for four orthopterans (Melanoplus fermur-rubrum, M. sanguinipes, Dissosteira carolina and Circotettix undulatus) and ten mammals (Microtus pennsylvanicus, Spermophilus columbianus, Sylvilagus nuttalli, Marmota monax, Antilocapra americana, Odocoileus virginianus, Odocoileus hemionus, Ovis canadensis, Cervus elaphus and Bison bison). The data collection methods have been provided in detail elsewhere (Belovsky 1978, 1981 a, b, c, 1984 b, c, d; Belovsky and Jordan 1978, 1981) and, unless previously unreported, will only be summarized here. During each month, data were collected for each species if the species was active (i.e., the adult grasshoppers are not active until late July; Spermophilus columbianus and Marmota flaviventris are hibernating by August). All parameter values appear in Table 3 along with the standard errors and sample sizes if the values were obtained from this study.

Constraint equation 1). Digestive capacity. Digestive capacity is measured as the product of the volume of the forager's organ(s) used for the breakdown of plant tissues (Table 3, parameter 2), and digestive turnover through the organ(s) (Table 3, parameter 3). For ruminants, the organs are the rumen-reticulum; for other tetrapods, they are the caecum and stomach; and for insects, the midgut and foregut. Organ capacity is obtained by killing animals and weighing the contents (wet weight) after the animals have fed ad libitum.

Digestive turnover can be measured by a number of methods. Animals can be fed foods 'labelled' with an indigestible marker (radioactive isotopes, e.g., Mautz and Petrides 1971; cotton thread, e.g., Campling et al. 1961) to measure rate of appearance of the marker in feces. Another method is to sacrifice a set of animals, who have had food provided ad libitum, and measure changes in digestive organ contents over a period of time (Storr 1963). Both techniques were used in my studies.

The 'labelled' food technique (cotton thread: see Belovsky 1984b) was used for Marmota flaviventris and Sylvilagus nuttalli. The sacrifice technique was used for Spermophilus columbianus, Microtus pennsylvanicus and orthopterans. Digestive turnover rate was determined using feeding trials for these species, where a mixed diet of monocots and dicots was provided ad libitum, and then 50 animals were sacrificed ( 5 every $30 \mathrm{~min}$ ). The digestive turnovers for the other larger mammals $(>3 \mathrm{~kg})$ were taken from the literature, as determined using 'labelled' foods. Digestive turnover is measured as $24 \mathrm{~h} \div$ mean retention time, where mean retention time (Moen 1973) is the expected time that a food particle is resident in the digestive tract.

The fill of digestive capacity by plants is measured as the ratio of wet (fresh) to dry weight. These values for monocots and dicots were based upon 10 samples for each plant species, 16 and 39 species, respectively (Table 1).

Constraint equation 2). Feeding time. To solve the linear programming model, the estimate of daily feeding time must represent a maximum value potentially available to the forager (Belovsky 1978, 1984d). A thermal physiology model has been employed to compute this value in previous studies (Belovsky 1981 b, 1984b) for herbivores. This esti-

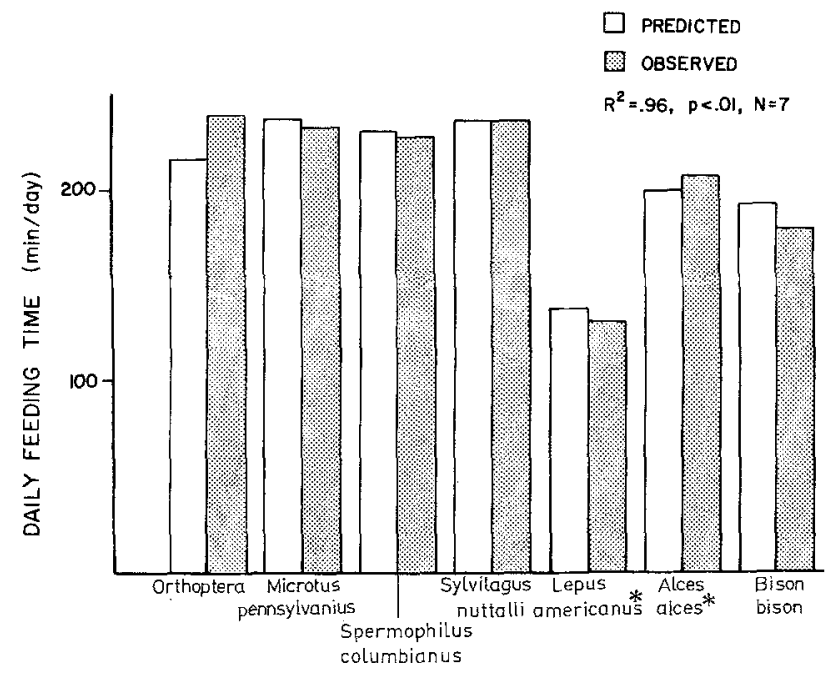

Fig. 1. A comparison of the thermal physiology-based estimate of daily feeding time and the observed daily feeding time are presented for 7 species of herbivores. Two species (marked with an asterisk) are included from a forest environment (Belovsky 1981 b, 1984b), indicating that the observation that daily feeding time is dependent on climate and the forager's thermal physiology may be a general condition

mate represents the maximum time the forager can feed given climate, its thermal physiology and different habitats that it can use in the environment. The model is constructed under the assumption that climate and periods when the digestive organ is unfilled set the upper limit for feeding time.

Computing a daily feeding time for 14 species over a five-year period based upon a thermal physiology model is very time consuming and is in progress (Belovsky, unpubl. data). At this time, however, a comparison of the observed daily feeding time and that predicted from the thermal model indicates that agreement is quite good (Fig. 1) for 5 species spanning the range of body sizes in the study.

Extrapolation of these findings to the remaining species is further substantiated by the observation that all 14 species demonstrate a common response in summer to increased daily air temperatures by reducing daily feeding time (Belovsky and Slade 1986). Therefore, observed daily feeding times were employed as estimates of maximum daily feeding times.

Under the worst scenario, if the observed daily feeding time is less than the thermal-based maximum value, which does not seem to be the case here, analysis of the foraging model is still illustrative. First, solutions to the time-minimizing goal are always independent of the daily feeding time constraint and this is usually the case for the digestive capacity-minimizing goal. Consequently, the model's predictions of these two goals are unaffected. On the other hand, if the energy-maximizing solution and the forager's observed behavior agree, then we are presented potentially with a case where the forager is an energy maximizer within a daily feeding time that is restricted by factors other than climate (e.g., required time for care of young, avoiding predators, etc.). These additional limits on feeding time may not be all-consuming as assumed in the time-minimizer hypothesis and this observation would indicate that the timeminimizing and energy-maximizing goals are not strict al- 
Table 3. Parameters measured to use in the linear-program diet optimization model for Bison Range herbivores during summer. Standard errors and ranges of sample sizes are given only for values from this study

Parameters and sample size range

\begin{tabular}{|c|c|c|c|c|}
\hline $\begin{array}{l}\text { Dissosteira } \\
\text { carolina } \\
0 \\
+\end{array}$ & $\begin{array}{l}\text { Circotettix } \\
\text { undulatus } \\
q\end{array}$ & $\begin{array}{l}\text { Melanoplus } \\
\text { sanguinipes } \\
q\end{array}$ & $\begin{array}{l}\text { Melanoplus } \\
\text { femur-rubrum } \\
\text { + }\end{array}$ & $\begin{array}{l}\text { Microtus } \\
\text { pennsylvanicus }\end{array}$ \\
\hline $\begin{array}{r}1.6 \times 10^{-3} \\
\pm 7.0 \times 10^{-4} \\
(6)\end{array}$ & $\begin{array}{l}7.7 \times 10^{-4} \\
\pm 1.68 \times 10^{-4} \\
(8)\end{array}$ & $\begin{aligned} & 3.59 \times 10^{-4} \\
& \pm 4.4 \times 10^{-5} \\
&(114)\end{aligned}$ & $\begin{array}{l}\quad 2.04 \times 10^{-4} \\
\pm \\
(54)\end{array}$ & 0.035 \\
\hline $\begin{array}{r}5.2 \times 10^{-2} \\
+4.2 \times 10^{-3} \\
(6)\end{array}$ & $\begin{array}{r}4.2 \times 10^{-2} \\
\pm 4.2 \times 10^{-3} \\
(8)\end{array}$ & $\begin{array}{l}2.32 \times 10^{-2} \\
+7.09 \times 10^{-3} \\
(114)\end{array}$ & $\begin{aligned} & 1.69 \times 10^{-2} \\
&+ 3.72 \times 10^{-3} \\
&(54)\end{aligned}$ & $\begin{array}{l}\quad 4.0^{\mathrm{c}} \\
\pm 0.6 \\
(26)\end{array}$ \\
\hline 3.87 & 3.60 & 3.50 & 4.09 & 7.8 \\
\hline $239.0^{z}$ & $239.0^{z}$ & $239.0^{z}$ & $239.0^{z}$ & $231.0^{\mathrm{d}, \mathrm{z}}$ \\
\hline $\begin{array}{r}1,100.0 \\
\pm 130.0\end{array}$ & $\begin{array}{r}2,860.0 \\
\pm 330.0\end{array}$ & $\begin{array}{r}6,250.0 \\
\pm 830.0\end{array}$ & $\begin{array}{r}10,000.0 \\
\pm 203.0\end{array}$ & $\begin{array}{l}21.17^{\mathrm{d}} \\
+2.86\end{array}$ \\
\hline $\begin{array}{r}280.0 \\
\pm 50.0\end{array}$ & $\begin{array}{r}580.0 \\
\pm 100.0\end{array}$ & $\begin{array}{l}\overline{7}, 140.0 \\
\pm 720.0\end{array}$ & $\begin{array}{r}7,690.0 \\
\pm 1,000.0\end{array}$ & $\begin{array}{l}10.97^{\mathrm{d}} \\
\pm 4.58\end{array}$ \\
\hline $\begin{array}{r}1.64 \\
\pm 0.09\end{array}$ & $\begin{array}{r}1.64 \\
\pm 0.09\end{array}$ & $\begin{array}{r}1.64 \\
\pm 0.09\end{array}$ & $\begin{array}{r}1.64 \\
\pm 0.09\end{array}$ & $\begin{array}{r}1.64 \\
\pm 0.09\end{array}$ \\
\hline $\begin{array}{r}2.67 \\
\pm 0.13\end{array}$ & $\begin{array}{r}2.67 \\
\pm 0.13\end{array}$ & $\begin{array}{r}2.67 \\
\pm 0.13\end{array}$ & $\begin{array}{r}2.67 \\
\pm 0.13\end{array}$ & $\begin{array}{r}2.67 \\
\pm 0.13\end{array}$ \\
\hline $7.04^{\mathrm{a}}$ & $7.04^{\mathrm{a}}$ & $7.04^{\mathrm{a}}$ & $7.04^{\mathrm{a}}$ & 8.84 \\
\hline $9.76^{a}$ & $9.76^{\mathrm{a}}$ & $9.76^{\mathrm{a}}$ & $9.76^{\mathrm{a}}$ & 9.63 \\
\hline $0.854^{b}$ & $0.528^{b}$ & $0.297^{\mathrm{b}}$ & $0.214^{\mathrm{b}}$ & $70.60^{\mathrm{g}}$ \\
\hline
\end{tabular}

8. Average energy requirement ( $2 \times$ basal: $\mathrm{KJ} /$ day $)$

a Bailey and Mukerji 1976, 1977; Smith 1959; Dyer and Bokhari 1976; Gyllenberg 1970; Husain et al. 1946; Bernays and Chapman 1972; Davey 1954; Dadd 1960

b Reichle 1968

- Kostelecka-Myrcha and Myrcha 1964; Lee and Horvath 1969; Belovsky 1984d

d These values determined from captive animals; Belovsky 1984d

e Data collected in 1980

f Data collected in 1978

ternatives as often conceptualized. Rather, they might represent endpoints of a continuum.

The feeding time values (time actually spent cropping foods) in this study (Table 3, parameter 4) were empirically determined by observing individual animals feed over the summer period in the field (Belovsky and Slade 1986). The only exception to this was Microtus pennsylvanicus which was observed in $0.2 \mathrm{~m}^{2}$ terraria with vegetation-covered sod present (Belovsky 1984d). This was necessary because $M i$ crotus could not be observed feeding in the field. A complete review of these data appears elsewhere (Belovsky and Slade 1986).

Cropping rate values (Table 3, parameter 5) are a major measurement required for this study because they are generally not available from the literature and are the most difficult to measure in the field. Determination of cropping rates requires the measurement of two parameters: the number or area of food items an herbivore ingests per unit time, i.e., leaves, blades, or $\mathrm{cm}^{2}$ consumed per minute, and the g Packard 1968; Wiegert 1961

h Karasov 1981

i Bailey 1965

j O'Gara 1970; and 2 measurements from our study

k Berwick 1968; and 3 measurements from our study

1 Short 1964; Short et al. 1969; Prins and Geilan 1971

m Short 1963; Short et al. 1965, 1966; Prins and Geilan 1971; Allo et al. 1973; Schoonveld et al. 1974; Dean et al. 1975

n Assumed same as white-tail deer (Mautz and Petrides 1971)

mean dry weight of an item of food. The number or area of items ingested per minute must be multiplied by the weights per item to obtain cropping rates ( $\mathrm{g} / \mathrm{minute}$ ).

The number of items ingested per minute was measured by observing herbivores larger than $100 \mathrm{~g}$ at close range ( $<25 \mathrm{~m}$ and usually $<10 \mathrm{~m}$ ) with binoculars or spotting scope. For the smaller herbivores (Microtus pennsylvanicus and grasshoppers), the number of food items or area ingested was measured by observation of the animals in cages or terraria $\left(0.2 \mathrm{~m}^{2}\right)$ containing sections of sod for Microtus or several food items for Orthoptera. The food was present for periods of time short enough to prevent food depletion ( $<20$ min duration). The number of bites of a food class was counted in two-minute periods for all the herbivore species except grasshoppers where the area of food items removed in $20 \mathrm{~min}$ was measured. Area removed was measured by tracing the food items on graph paper before feeding and comparing the item with the tracing after feeding to estimate the region that had been consumed. 
Table 3

\begin{tabular}{|c|c|c|c|c|c|c|c|c|}
\hline \multicolumn{9}{|c|}{ Herbivore species } \\
\hline 0.35 & 1.0 & 2.5 & 46.0 & 72.0 & 80.0 & 90.0 & 318.0 & 636.0 \\
\hline 7.3 & 6.9 & 4.7 & $1.14^{\mathrm{n}}$ & $1.14^{\mathrm{n}}$ & $1.14^{\mathrm{a}}$ & $1.14^{\mathrm{n}}$ & $0.45^{\mathrm{u}}$ & $0.3^{v}$ \\
\hline $228.0^{e, z}$ & $236.0^{f, z}$ & $196.0^{\mathrm{f}, \mathrm{z}}$ & $218.0^{z}$ & $209.0^{z}$ & $203.0^{z}$ & $199.0^{z}$ & $181.0^{z}$ & $178.0^{z}$ \\
\hline $\begin{aligned} & 1.37^{\mathrm{e}} \\
\pm & 0.10\end{aligned}$ & $\begin{array}{r}0.38^{\mathrm{f}} \\
\pm 0.048\end{array}$ & $\begin{array}{r}0.29^{f} \\
\pm 0.021\end{array}$ & $\begin{array}{c}0.08 \\
\pm 0.007\end{array}$ & $\begin{array}{r}0.086 \\
\pm 0.005\end{array}$ & $\begin{array}{c}0.10 \\
\pm 0.007\end{array}$ & $\begin{array}{c}0.09 \\
\pm 0.007\end{array}$ & $\begin{array}{r}0.056 \\
+0.005\end{array}$ & $\begin{array}{r}0.045 \\
\pm 0.007\end{array}$ \\
\hline $\begin{array}{r}1.64 \\
\pm 0.09\end{array}$ & $\begin{array}{r}1.64 \\
\pm 0.09\end{array}$ & $\begin{array}{r}1.64 \\
\pm 0.09\end{array}$ & $\begin{array}{r}1.64 \\
\pm 0.09\end{array}$ & $\begin{array}{r}1.64 \\
\pm 0.09\end{array}$ & $\begin{array}{r}1.64 \\
\pm 0.09\end{array}$ & $\begin{array}{r}1.64 \\
\pm 0.09\end{array}$ & $\begin{array}{r}1.64 \\
\pm 0.09\end{array}$ & $\begin{array}{r}1.64 \\
\pm 0.09\end{array}$ \\
\hline $\begin{array}{r}2.67 \\
\pm 0.13\end{array}$ & $\begin{array}{r}2.67 \\
\pm 0.13\end{array}$ & $\begin{array}{r}2.67 \\
\pm 0.13\end{array}$ & $\begin{array}{r}2.67 \\
\pm 0.13\end{array}$ & $\begin{array}{r}2.67 \\
\pm 0.13\end{array}$ & $\begin{array}{r}2.67 \\
\pm 0.13\end{array}$ & $\begin{array}{r}2.67 \\
\pm 0.13\end{array}$ & $\begin{array}{r}2.67 \\
\pm 0.13\end{array}$ & $\begin{array}{r}2.67 \\
\pm 0.13\end{array}$ \\
\hline 9.46 & 10.51 & 11.01 & $9.63^{\mathrm{n}}$ & $12.14^{y}$ & $9.63^{\mathrm{n}}$ & $9.63^{n, r}$ & $10.22^{\mathrm{x}, \mathrm{w}}$ & $12.40^{\mathrm{w}}$ \\
\hline 10.22 & 11.35 & 11.93 & $10.05^{\mathrm{n}}$ & $12.48^{y}$ & $10.05^{\mathrm{n}}$ & $10.05^{\mathrm{n}, \mathrm{r}}$ & $16.67^{\mathrm{x}, \mathrm{w}}$ & $14.66^{w}$ \\
\hline $196.4^{\mathrm{h}}$ & 586.26 & $1,624.79^{\mathrm{i}}$ & $8,618.1^{\circ}$ & $11,377.7^{p}$ & $9,853.4^{\mathrm{a}}$ & $10,766.3^{\mathrm{r}}$ & $46,352.6^{x}$ & $74,250.4$ \\
\hline
\end{tabular}

- Wesley et al. 1970, 1973

p Chappel and Hudson 1978a, 1980

q Silver et al. 1971

$r$ Short 1981

s Murie 1951; Prins and Geilan 1971; Nagy and Regelin 1975; Church and Hines 1978; and data from this study

- Meagher 1973; and ten from our study

u Maloiy and Kay 1971; Staines 1976; Milne et al. 1976; Dean et al. 1980

Only observations which entailed the herbivore's cropping of a single food class were used to compute cropping rates. Mixed observations do not allow determination of the food-cropping rates for each of the food categories in an independent manner.

To obtain the number of items ingested per minute, the bites/minute values must be multiplied by the number of items/bite. The number of items/bite is often a difficult measure to obtain in the field for bison, elk, bighorn sheep, deer, pronghorn antelope, marmots, cottontails and ground squirrels. Fortunately, semi-tame animals were present at the study site. These were animals either raised in captivity and turned free or naturally unafraid of humans because of the absence of hunting. Semi-tame animals permitted very close observations at times $(<2 \mathrm{~m})$ which enabled measurement of the items/bite. This was not a problem for the species observed in captivity.

By observing the herbivores in the field or in captivity at close range $(<20 \mathrm{~m})$, the plants on which they fed could $\checkmark$ Schaefer et al. 1978

w Peden 1971; Richmond et al. 1977; Schaefer et al. 1978; Hawley et al. 1981

x Nelson and Leege 1982

y from Ovis aries, Milne 1976; Arman and Hopcraft 1975; Blaxter 1962

z Belovsky and Slade 1986

be relocated and the size of the items consumed was measured using calipers (width for monocot blades and diameter for dicot stems or petioles). These plant measurements ('eaten remainder') were matched using calipers to a plant of similar size which was then clipped, and the portion equivalent to that consumed ('matched bite') was separated, saved, dried and weighed to provide the weight/item. For grasshoppers, the known area of a food item was collected, dried and weighed to measure the conversion of area ingested to weight.

For the estimates of cropping rate, based on the products of the above values, a standard deviation must be computed. Because bites/min, items/bite and weight/item are too difficult to measure simultaneously for a given individual forager, a simple measure of standard deviation using the products of these values is not possible. For the product of independent variables, the standard deviation was estimated as: $[(\operatorname{VAR}(\mathrm{XY})=\operatorname{VAR}(\mathrm{X}) \operatorname{VAR}(\mathrm{Y})+\mathrm{E}(\mathrm{X}) \operatorname{VAR}(\mathrm{Y})+$ E(Y)VAR(X)] (Snedecor and Cochran 1967; Travis 1982). 
This formula, however, provides an overestimate of the standard deviation because the bites/min, items/bite and weight/item are not independent measures and they covary negatively (Hudson and Nietfeld 1985; Wickstrom et al. 1984). Negative covariation reduces the standard deviation estimate based upon an assumption of independence (Snedecor and Cochran 1967; Travis 1982). I could not compensate for negative covariation because the three parameters were not measured simultaneously in my study.

Constraint equation 3). Energetic requirements. Each herbivore's energy requirements were taken from metabolic studies in the literature. If studies were not available in the literature, the energy expenditures were computed using the standard body weight-metabolic function (Kleiber 1961; Hemmingsen 1960), increased two times for an active life (Moen 1973). This metabolic value was chosen to reflect a minimum intake needed for an individual's survival and replacement reproduction (one surviving offspring/lifetime), the basis for the time-minimizer foraging goal (Schoener 1971). Furthermore, this minimum value should not be confused with observed measures of energy budgets or maximum physiological values, rather it reflects a hypothetical value. These energy requirements appear in parameter 8 of Table 3 .

The net energy content of food plants (Table 3, parameter 7) was measured as the product of gross energy content of the average plant within a food class and its average digestibility to the herbivore. Monocot and dicot gross energy contents were, respectively, $18.4 \mathrm{KJ} / \mathrm{g}$-dry wt and 20.1 $\mathrm{KJ} / \mathrm{g}$-dry wt (Golley 1961; unpublished work, Bison Range files). For species in a given plant class, these values were found to be fairly constant (Golley 1961).

Measurements of the food plant's digestibility to each herbivore are often available in the literature. When not available, the digestibility measures for each herbivore were made using captive animals. Digestibility was measured as dry matter disappearance of the food (1-dry wt of feces/dry wt of ingested food). These measurements only had to be made for the smaller herbivores (marmot, cottontail, ground squirrel, Microtus and grasshopper species). This was accomplished by feeding captive animals various plant species in each food class in ad libitum quantities. The dry weight of food ingested was measured as well as fecal production over $24 \mathrm{~h}$ to compute digestibility.

Constraint equation 4). Nutrient requirements. No nutrient constraint seemed necessary to explain these herbivores' foraging. Either sodium (Botkin et al. 1973; Belovsky and Jordan 1981; Belovsky 1981 c; Jordan et al. 1973; Weeks and Kirkpatrick 1976; Denton et al. 1961; Denton 1956, 1957, 1965; Bott et al. 1964; Scoggins et al. 1970; Bakko 1977; Weir 1972, 1973; Jarman 1972; Aumann 1965; Aumann and Emlen 1965; Hutchinson and Deevey 1949; Kimmins 1970) or protein (Schwartz et al. 1977; Bell 1969, 1971; Gwynne and Bell 1968; Owen-Smith and Novellie 1982; Klein 1962; Klein and Schønheyder 1970; Moen 1973; Murphy and Coates 1966) often are considered to be potentially important as limiting nutrients to herbivores.

The sodium and protein content of plant species at the study site were taken from the literature for sites with similar environmental conditions. The average sodium content for a number of plant species at the Bison Range was 400 times greater than for plant species in areas where sodium appeared to influence herbivore foraging $(0.04 \%$ vs. $0.0001 \%$ by weight). Crude protein averaged $12.3 \%$ over the summer and $17.7 \%$ over the period of peak parental investment in reproduction; approximately $6-7 \%$ is required for maintenance and $13-16 \%$ for growth and reproduction (French et al. 1955). Only during the period of peak parental investment (lactation) might protein be constraining. Therefore, nutrient impacts on foraging were not considered important in this study. If a model without nutrient constraints fails to predict diet choice, then a protein constraint would be a possible addition for further study.

Herbivore diet. The observed herbivore diets were measured using microhistological analysis of the plant fragments in feces or stomach contents (Sparks and Malechek 1968). The proportion of monocots and dicots was determined for each sample. Each herbivore's diet for the summer was computed as the average of its average monthly diets. The monthly estimates were based upon a minimum of 15 samples. Generally, stomach samples were used for herbivores smaller than Spermophilus columbianus (350 g), stomach and fecal samples were used for Spermophilus columbianus and Marmota flaviventris $(2.5 \mathrm{~kg})$, and fecal samples were primarily used for Sylvilagus nuttalli and larger herbivores $(>3 \mathrm{~kg})$.

Diet values obtained by microhistological analysis were scaled by relative digestibility to account for differential appearance of monocots or dicots (Smith and Shandruk 1979). This was accomplished by scaling the observed counts of monocots and dicots by their dry matter digestibility for each herbivore species (Table 3, parameter 7). Although there are some difficulties with this technique in estimating species composition of an herbivore's diet (Smith and Shandruk 1979), it appears adequate for predicting diet composition by food classes which is the goal of the model.

These measures of an herbivore's diet are well suited for testing the linear programming solutions, because they do not employ any of the observations used for estimating the model parameters as do other diet-estimating techniques (e.g., cropping rates times feeding times).

The linear programming model. The digestive capacity, daily feeding time and energy-requirement constraints can be written as:

$C>$ or $<a_{1} g+a_{2} d$

where $C$ is the foraging constraint and $a_{1}$ or $a_{2}$ converts the dry matter intake of monocots $(g)$ or dicots $(d)$, respectively, into the units of $C$. Because there are only two food classes (monocots and dicots), the linear programming solutions to the various goals, if they exist, occur at the intersections of two constraint equations or of a constraint equation and an axis (Belovsky 1978, 1984d). One of the three constraints drops out of the analysis for each of the three goals because it becomes the goal or object of foraging: for energy maximization, the energy constraint drops out; for feeding time minimization, the daily foraging constraint drops out; and for digestive capacity minimization, the digestive constraint drops out. For a review of linear programming techniques, see Strum (1972).

\section{Results and discussion}

Foraging by each species. The data necessary to construct the linear programming model for each of the 14 Bison 
b

Bison bison a Microtus pennsylvanicus

MONOCOT INTAKE

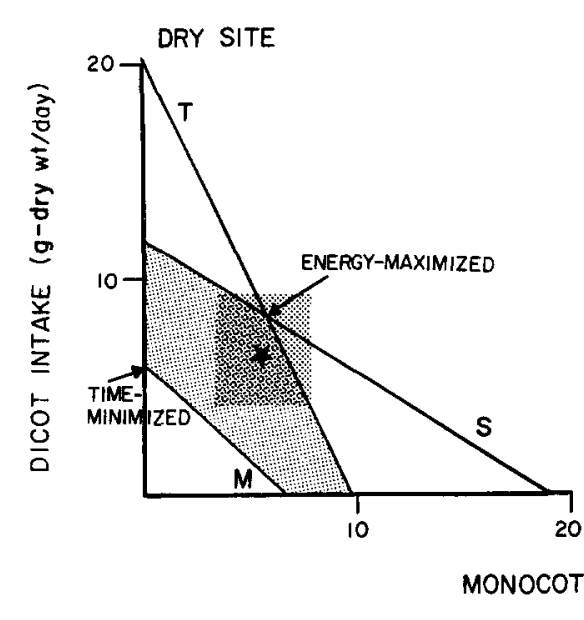

TIME (T):

$231 \mathrm{~min} /$ day $\geq 21.17 \mathrm{~g}+10.97 f$

DIGESTIVE CAPACITY (S):

$31.2 \mathrm{~g}-$ wet/day $\geq 1.64 \mathrm{~g}+2.67 \mathrm{f}$

MAINTENANCE + REPRODUCTIVE METABOLISM (M):

$70.6 \mathrm{KJ} /$ day $\leq 8.84 \mathrm{~g}+9.63 \mathrm{f}$

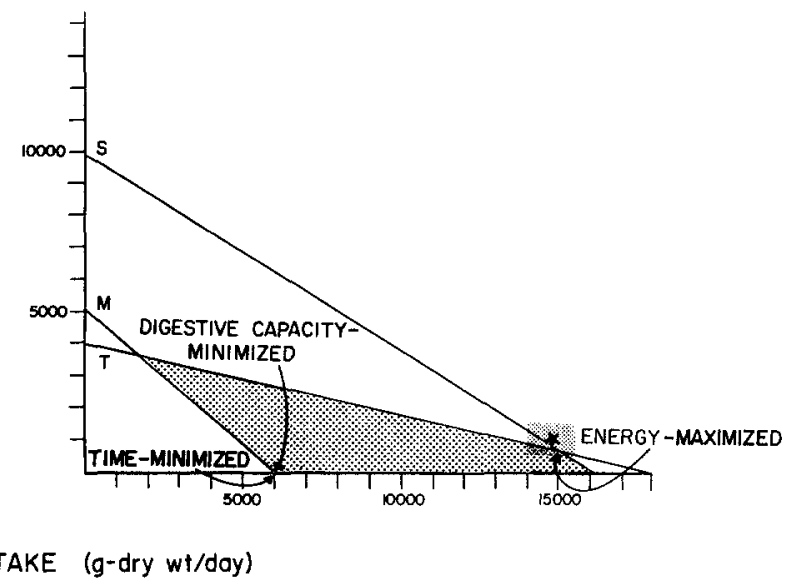

TIME (T):

$178 \mathrm{~min} / \mathrm{day} \geq 0.01 \mathrm{~g}+0.045 f$

DIGESTIVE CAPACITY (S):

$26310 \mathrm{~g}$-wet/day $\geq 1.64 \mathrm{~g}+2.67 \mathrm{f}$

MAINTENANCE + REPRODUCTIVE METABOLISM (M):

$74250.4 \mathrm{KJ} /$ day $\leq 12.40 \mathrm{~g}+14.66 \mathrm{f}$

Fig. 2a, b. Linear programming solutions are graphically presented for Microtus a and bison b. The lighter shaded region represents the region of feasible diets that satisfies the forager's constraint equations. The time-minimizing, energy-maximizing and digestive-capacityminimizing solutions are presented for comparison with the observed diet $(\star)$. The $95 \%$ confidence region of the observed diet is presented by the darker shaded rectangle. The Microtus possesses the largest confidence interval of all the species studied and the bison has the lowest

Range herbivores appear in Table 3. Examples of time-minimizing, energy-maximizing, and digestive capacity-minimizing solutions to the linear programming model appear in Fig. 2, along with the observed diets for two of the 14 species, bison and Microtus. These two species were chosen as examples since they provide comparisons between the model's predictions and the observed diets for conditions with the greatest potential error (Microtus) and with the lowest potential error (bison). Therefore, these two examples represent the best and worst possible cases of the 14 species studied. Microtus have a large potential error in their observed diets because they were measured using stomach contents, and for such a small species its small digestive capacity can be filled in a single meal which may not reflect the daily diet (Belovsky 1984a).

Figure 3 presents a comparison of the linear programming model's predictions for time-minimizing and energymaximizing diets with the observed diets for the 14 species. The $45^{\circ}$ angle line in the plots represents perfect prediction of the observed diets by the model. The comparison indicates that the energy-maximized solution to the model predicts the observed diet very well $\left(r^{2}=0.99, n=14, P<0.001\right)$, even though the time-minimized solution also provides a statistically significant correlation $\left(r^{2}=0.50, n=14, P<\right.$ 0.05 ). Another alternative strategy of digestive capacity minimization provides a poor fit with observed diets $\left(r^{2}=\right.$ $0.06, n=14$, n.s.).

The diet resulting if the herbivores choose their foods at random, that is, take foods as they are encountered, would be a constant of approximately $70 \%$ monocots by weight $\left(r^{2}=\right.$ undefin., $n=14$, n.s.). This is not observed. In conclusion, the energy-maximized linear programming model gives the best fit by far for diet in these herbivores.

To further examine the model's predictions, a $\chi^{2}$ goodness of fit test can be used to compare the predicted and observed diets for each of the 14 species. For each species' diet determination, a known number of plant fragments had been counted in the stomach or fecal analysis. Each fragment is approximately equal in size since the samples are ground through a given-sized screen. Consequently, the number of fragments counted were considered as independent samples. An expected value for each $\chi^{2}$-cell was computed as the predicted diet proportion times the total number of fragments counted, which is compared with the observed fragments counted for the cell. The $\chi^{2}$-test has one degree of freedom since it has two cells (monocots and dicots).

$\mathrm{A} \chi^{2}$-test was employed for several reasons, rather than a $t$-test, to compare the observed mean diet and standard deviation to a predicted value as portrayed in Fig. 2. First, the computation of a mean and standard deviation is misleading since it would require the averaging of monthly values which would unrealistically inflate the standard deviation by expressing diet variation between months and not samples. Second, the standard deviation may be inflated if it measures the variation between stomach contents that arise from meal and not diet choice (see above). Third, the $t$-test would tend to underestimate differences between the predicted and observed diets due to the small sample sizes based on monthly averages and their large standard 


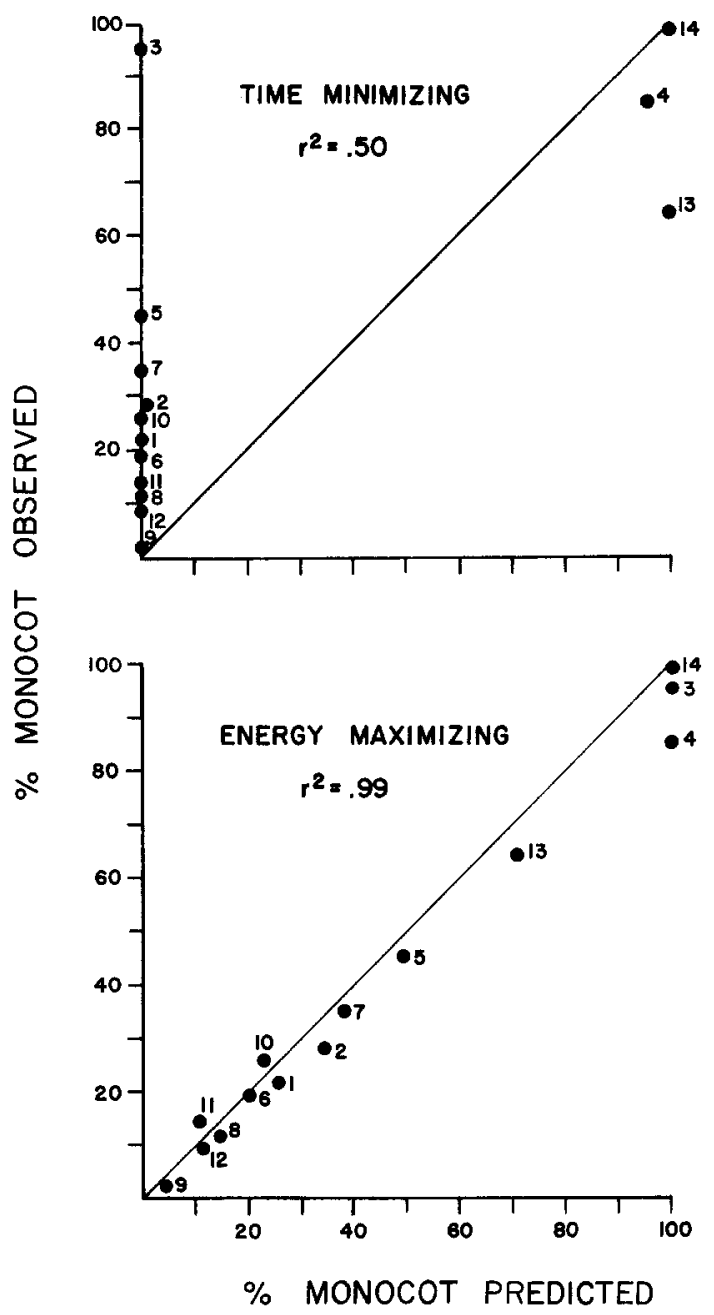

Fig. 3. The time-minimized and energy-maximized diets predicted by the linear programming model versus the observed diets are presented, demonstrating that time-minimizers are predicted to be either monocot or dicot specialists. The energy-maximizing diet explains the observed diets better. Each number represents a different species: 1 Melanoplus femur-rubrum, 2 Melanoplus sanguinipes, 3 Circotettix undulatus, 4 Dissosteira carolina, 5 Microtus pennsylvanicus, 6 Spermophilus columbianus, 7 Sylvilagus nuttalli, $8 \mathrm{Mar}$ mota flaviventris, 9 Antilocapra americana, 10 Ovis canadensis, 11 Odocoileus virginianus, 12 Odocoileus hemionus, 13 Cervus canadensis (or elaphus), and 14 Bison bison

deviations. Therefore, a $\chi^{2}$-test was more likely to find the model predictions different from the observed diets.

Based upon the $\chi^{2}$-test, the time-minimized diet is significantly different from the observed diet for all species but bison and Dissosteira carolina, but their observed feeding times are much greater than that predicted for time minimization. Only the observed diet for elk (Cervus elaphus) was not significantly different $(P>0.05)$ from a random diet. Three of the 14 diets predicted to minimize digestive capacity were not different from observed (Dissosteira carolina, Circotettix undulatus, and Bison bison); however, the observed feeding times for these species were very different from those of a digestive-capacity minimizer. None of the energy-maximized diets were different from observed.

Even though the elk's observed diet is not different from random foraging, it also is not different from the energy-
Table 4. Predicted and observed feeding times for pronghorn antelope with different reproductive statuses are presented, along with sample sizes and t-test values

\begin{tabular}{llll}
\hline & $\begin{array}{l}\text { Energy } \\
\text { maximizer }\end{array}$ & $\begin{array}{l}\text { Time } \\
\text { minimizer }\end{array}$ & Observed \\
\hline $\begin{array}{l}\text { Doe or non- } \\
\text { reproductive } \\
\text { buck }\end{array}$ & $218 \mathrm{~min} /$ day & $69 \mathrm{~min} /$ day & $218 \mathrm{~min} /$ day \\
$\begin{array}{l}\text { Subordinate } \\
\text { reproductive } \\
\text { buck }\end{array}$ & $\begin{array}{l}218 \mathrm{~min} / \text { day } \\
t=0.42\end{array}$ & $\begin{array}{l}69 \mathrm{~min} / \text { day } \\
t=1.1\end{array}$ & $\begin{array}{l}177 \pm 94 \mathrm{~min} / \text { day } \\
(n=11)\end{array}$ \\
$\begin{array}{l}\text { Dominant } \\
\text { reproductive } \\
\text { buck }\end{array}$ & $\begin{array}{l}218 \mathrm{~min} / \text { day* } \\
t=7.2\end{array}$ & $\begin{array}{l}69 \mathrm{~min} / \text { day } \\
t=0.80\end{array}$ & $\begin{array}{l}84 \pm 17 \mathrm{~min} / \text { day } \\
(n=5)\end{array}$ \\
\hline
\end{tabular}

* $P<0.05$

maximized diet. This suggests that given the elk's feeding characteristics and the Bison Range environment, the best elk diet might be provided by eating foods as they are encountered, but this still provides an energy-maximizing diet. In the three cases in which the predicted diets that minimize digestive capacity or the two cases in which the predicted time-minimizing diets are not different from the observed diet, the energy-maximizing prediction still provides as good or a better fit. Therefore, all 14 herbivores appear to forage as energy maximizers, even though they are very different in body size, digestive physiology and taxonomic affiliation.

Because all the herbivores examined here appear to be energy maximizers, the question arises why herbivores might be energy maximizers rather than time or digestivecapacity minimizers. Perhaps herbivores are energy maximizers to survive either long-term (winter) or short-term (reproductive) energetic deficiencies (Belovsky 1984d). These deficiencies might arise from either low food abundance or the low digestibility of plants with a low nutritional quality per unit bulk. The latter requires herbivores to process foods relatively slowly to extract nutrients while the food bulk rapidly fills digestive capacity. The net result to the animal may be the inability to acquire adequate energy intake in some short time period and consequently the need to store energy reserves. Therefore, herbivores may consistently need to acquire as much energy as possible.

One might wonder whether a time minimizer is a realistic, observable alternative, or simply a "straw-man". For this purpose, male and female pronghorn antelope were observed during the mating season (approximately September 7-31), and their daily foraging time was recorded. Solving the linear programming model and comparing the solutions with the observed feeding times (Table 4), we find that dominant males which perform most of the mating (Kitchen 1974) appear to be time minimizers, while females and non-reproductive males are still energy maximizers. Subordinate but reproductive males are intermediate in their daily feeding time. This occurs because males spend large portions of their time fending off other males from their herds of females rather than feeding. Therefore, a time-minimizing strategy is observable.

Another question of concern is whether the observed and/or predicted diets vary between years. It is possible that the forager selects a diet which is close to some opti- 
Table 5. The 1980 daily feeding-time and cropping-rate constraints for two herbivores at the Bison Range are presented. Sample sizes are presented in parentheses

\begin{tabular}{|c|c|c|c|}
\hline & \multirow[t]{2}{*}{$\begin{array}{l}\text { Feeding time } \\
\text { (min/day) }\end{array}$} & \multicolumn{2}{|c|}{$\begin{array}{l}\text { Cropping rate } \\
\text { (min/g-dry wt) }\end{array}$} \\
\hline & & Monocot & Dicot \\
\hline Sylvilagus nuttalli & $\begin{array}{l}236 \\
(71 \text { animal } \mathrm{h})\end{array}$ & $\begin{array}{l}0.71 \pm 0.11 \\
(81 \mathrm{~min})\end{array}$ & $\begin{array}{l}0.46 \pm 0.06 \\
(57 \mathrm{~min})\end{array}$ \\
\hline Marmota flaviventris & $\begin{array}{l}242 \\
(323 \text { animal } h)\end{array}$ & $\begin{array}{l}0.67 \pm 0.29 \\
(134 \mathrm{~min})\end{array}$ & $\begin{array}{l}0.35 \pm 0.03 \\
(242 \mathrm{~min})\end{array}$ \\
\hline
\end{tabular}

Table 6. The predicted time-minimized and energy-maximized diets are presented for two species in 1980 for comparison to their 1978 diets

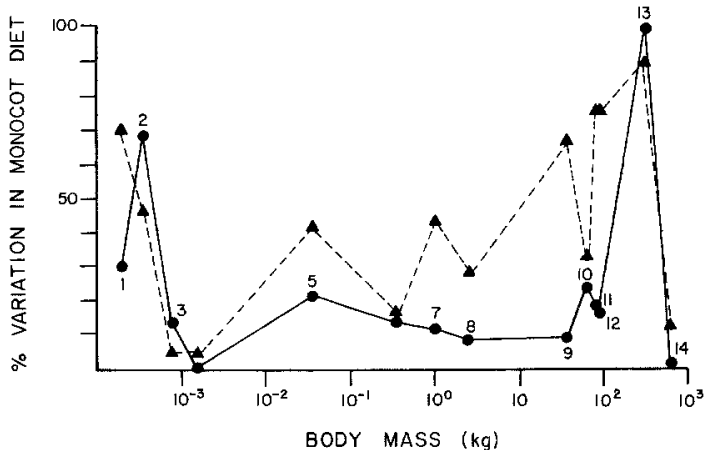

Fig. 4. Species body mass is plotted against the percent variation in the summer diets (maximum \% monocot intake minus minimum $\%$ monocot intake) predicted by the energy-maximized solution to the linear programming model when the parameters are allowed to vary by $10 \%$ (sensitivity analysis ) ( $\bullet$ ). This represents the plasticity of different species or body sizes in their diets. The maximum variation in diet found in the literature or this study (Allen 1968; Alldredge et al. 1974; Anderson et al. 1965; Anthony 1976; Anthony and Smith 1974; Barmore 1969; Bartmann et al. 1982; Beale and Smith 1970; Becker 1972; Berwick 1968; Blood 1967; Boeker et al. 1972; Bookhout 1965; Brown 1961; Bryant et al. 1979; Buechner 1947; Buechner 1950; Buechner 1952; California Wildlife Investigations Laboratory, N.d.; Chamrad and Box 1968; Cliff 1939; Cole 1969; Collins and Unness 1983; Collins et al. 1978; Constan 1972; Couey 1946; Cowan 1945; Cowan 1947; Currie et al. 1977; Dailey 1980; DeNio 1938; Deschamp et al. 1979; Dirsch1 1963; Dorn 1970; Drawe 1968; Dusek 1975; Everitt and Drawe 1974; Everitt and Gonzalez 1979; Ferrel and Leach 1949; Ferrel and Leach 1950a; Ferrel and Leach 1950b; Free et al. 1970; Gordon 1968; Greer et al. 1970; Halloran 1943; Halls 1978; Hanley 1980; Hanley and Hanley 1982; Hansen and Clark 1977; Hansen and Dearden 1975; Harper 1962; Harper et al. 1967; Hill and Harris 1943; Hlavachick 1968; Hobbs et al. 1983; Hobbs et al. 1981; Hubbard and Hansen 1976; Hungerford 1970; Jameson 1947; Joern 1979; Johnson 1979; Johnson and Hansen 1979; Keller 1975; Klebenow 1965; Korschgen et al. 1980; Krausman 1978; Kufeld 1973; Kufeld et al. 1973; Lauer and Peek 1976; Leach 1956; Leach and Hiehle 1957; Leopold et al. 1951; Lovaas 1958; MacCracken and Hansen 1981; Mackie 1970; Martinka 1968; Mason 1952; McCollough et al. 1980; McCulloch 1969; McCulloch 1973; McCulloch 1978; McCullough 1980; McMahan 1964; Meagher 1973; Mitchell and Smoliak 1971; Morris and Schwartz 1957; Mulkern et al. 1969; Neff 1974; Nellis and Ross 1969; Nelson and Burnell 1975; O'Gara and Greer 1970; Oldemeyer et al. 1971; Peden 1976; Peden et al. 1974; Pickford and Reid 1943; Reynolds et al. 1978; Schwartz and Nagy 1976; Schwartz et al. 1977; Seegmiller and Ohmart 1981; Severson and May 1967; Severson et al. 1968; Sexson et al. 1981; Shank 1982; Short 1977; Smith 1952; Smith 1965; Smith and Shandruk 1979; Smith et al. 1979; Smith and Julander 1953; Spalinger 1980; Stevens 1966; Stevens 1974; Stormer and Bauer 1980; Taber and Dasmann 1958; Taylor 1972; Telfer 1967; Telfer 1972; Todd 1975; Ueckert 1968; Ueckert et al. 1972; Urness 1981; Uzzell 1958; Wallmo 1981; Wallmo and Regelin 1981; Wallmo et al. 1973; Wilkins 1957; Willms and McLean 1978; Willms et al. 1979; Willms et al. 1980; Zimmerman 1965 ) is plotted for comparison (A), indicating that the sensitivity analysis of the linear programming model reflects observed sensitivity (Spearman Rank Correlation $=0.69, P<0.005$ ). The numbers refer to the species in Fig. 3 and provide a ranking by body size. The smaller peaks in monocot consumption at species 5 and 7 may be real but were considered either as sampling variation or of minor importance

10-20\% deviations, 3 had $20-30 \%$ deviations, 1 had a $60-70 \%$ deviation and 1 had a $90-100 \%$ deviation.

The fact that 5 of 14 species have predicted diet deviations over $20 \%$ is disconcerting (Fig. 4). Moreover, given considered the most sensitive for the species' model. Four species had maximum diet deviations less than $10 \%, 5$ had 
the confidence intervals for the observed constraints, the probability that their true values fall within $10 \%$ of the observed value is only 0.40 (range $0.01-0.80$ ). The daily feeding time and cropping rate constraint equations are generally the most sensitive for the model. The difficulty in reducing the chance of error for this constraint arises because of the inherent spatial variability of food abundance in the environment and little can be done to reduce this factor within reasonable sampling time in the field.

Although the sensitivity of the linear programming model for some species is upsetting from the viewpoint of the modeller, this sensitivity may be biologically important. Figure 4 also contains a plot of the maximum diet deviation reported in the literature or taken from this study for the 14 species (maximum \% monocots observed in the diet minus minimum $\%$ monocots observed in the diet). The reported variability in these herbivores' diets is correlated with their diet sensitivity predicted by the linear programming model (Spearman Rank Correlation $=0.69, n=14$, $P<0.001$ ). This high correlation is very surprising since the literature studies do not portray a uniform range of foraging environments for each of the species, making the correlations' strengh even more convincing.

The diet sensitivity for the models may reflect the ability of these herbivores to vary their diets with environmental variability. Furthermore, the high level of sensitivity of the models for some species may be unavoidable because they reflect real biological sensitivity. It is also interesting that the species which show the greatest model sensitivity are those whose diets are in a region of transition from monocots to dicots or dicots to monocots (Circotettix undulatus, Microtus pennsylvanicus, Cervus elaphus), i.e., a diet tending to be balanced between monocots and dicots. These foragers generally have daily feeding time and digestive capacity constraints that are very similar in magnitude (see below).

Sensitivity of the model for the feeding time- and digestive capacity-minimizing solutions is far less than that for the energy-maximizing solutions. Sensitivity of the model for these solutions is inconsequential. For example, on average, the forager's energy requirements would have to vary by at least 2.1-fold (range: 1.1- to 6.2-fold) for the feeding time-minimizing goal to change the predicted diet. This amount of variation in the energy constraint would necessitate energy requirements that are approximately 4.2 times basal metabolism (range: 2.2 to 12.4 times), which is equal to or greater than the maximum energy requirements reported in the literature (Moen 1973).

Finally, the model's high sensitivity does not diminish our confidence in the observation that these herbivores appear to forage as energy maximizers. This is because the models for the 14 species serve as independent tests of the alternative foraging hypotheses, making the overall conclusion, in essence, a non-parametric test, freed of the parametric estimates and sensitivity of species by species analyses. Therefore, the conclusion that these herbivores appear to forage as energy maximizers is quite robust.

Body size: the importance for different foraging constraints and for plant defense. Since all of the herbivores studied forage as though they are energy maximizers, and the same foraging constraints are operating to delimit this goal (feeding time and digestive capacity), then the only difference between these herbivores' foraging strategies is the constraint values which might scale with body size. We can

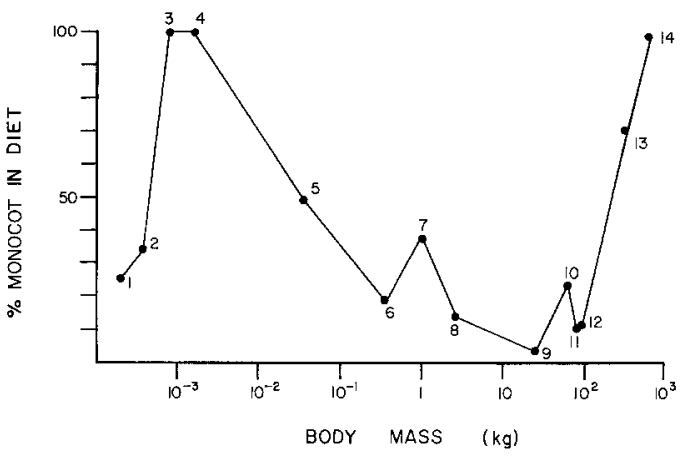

Fig. 5. Each Bison Range herbivore's summer diet (\% monocot), as predicted by the energy-maximized solution to the linear programming model, is plotted against the species' adult body mass (obtained from either this study or Burt and Grossenheider 1964). The numbers associated with each point refer to the species names presented in Fig. 3.

then ask if there is a pattern of diet selection for energymaximizers with body size. Figure 5 presents the energymaximized predicted diets expressed as \% of monocot in the diet plotted against body mass. Two peaks of monocot consumption (Fig. 5: $10^{-3}-10^{-2} \mathrm{~kg}$ and $10^{2}-10^{3} \mathrm{~kg}$ ) and two peaks of dicot consumption (Fig. $5: 10^{-4}-10^{-3} \mathrm{~kg}$ and $10^{-1}-10^{2} \mathrm{~kg}$ ) are observed. This indicates that there is a wider range of body sizes that selects diets higher in dicots than monocots, 4 orders of magnitude vs 2 .

The size classes which are heavy monocot feeders $\left(10^{-3}-10^{-2} \mathrm{~kg}\right.$ and $\left.10^{2}-10^{3} \mathrm{~kg}\right)$ are characterized by monocot consumption constrained by digestive capacity and by dicot intake constrained by feeding time or digestive capacity. Body size classes which are predominantly dicot feeders $\left(10^{-4}-10^{-3} \mathrm{~kg}\right.$ and $\left.10^{-1}-10^{2} \mathrm{~kg}\right)$ are constrained in their monocot consumption by feeding time while dicot consumption is limited by digestive capacity.

Very few body sizes have balanced (near equal) digestive capacity and feeding time constraints for both dicot and monocot ingestion. This condition leads to a diet balanced between monocots and dicots, i.e., equal ingestion of both foods. Consequently, most herbivores will tend to specialize (consume more) on either monocots or dicots.

The feeding time constraint, in general, appears to be limiting since it most often determines which food class does not dominate the diet. The observed changes in the importance of the constraints (feeding time or digestive capacity) on monocot versus dicot ingestion may arise from the impact of body geometry on mouth size, speed of search for food, energy metabolism, digestive organ capacity and digestive turnover (Belovsky, in prep.).

From the above pattern of diet choice and body mass, we might be tempted to generalize about the defensibility of monocots versus dicots. We might conclude that monocots (primarily graminoids) are better defended against herbivores (less acceptable) than dicots, since a smaller range of herbivore sizes can utilize large quantities of monocots ( 2 vs. 4 orders of magnitude of body sizes). "Defense" is used here in reference to the acceptability of the food plant to the herbivore whether acceptability is determined by toxicity, low nutrient content, or low digestive capacity due to bulk or slow turnover. This illustrates the difficulty in trying to define plant defenses against herbivores based on the study of a single herbivore species or a single factor, 


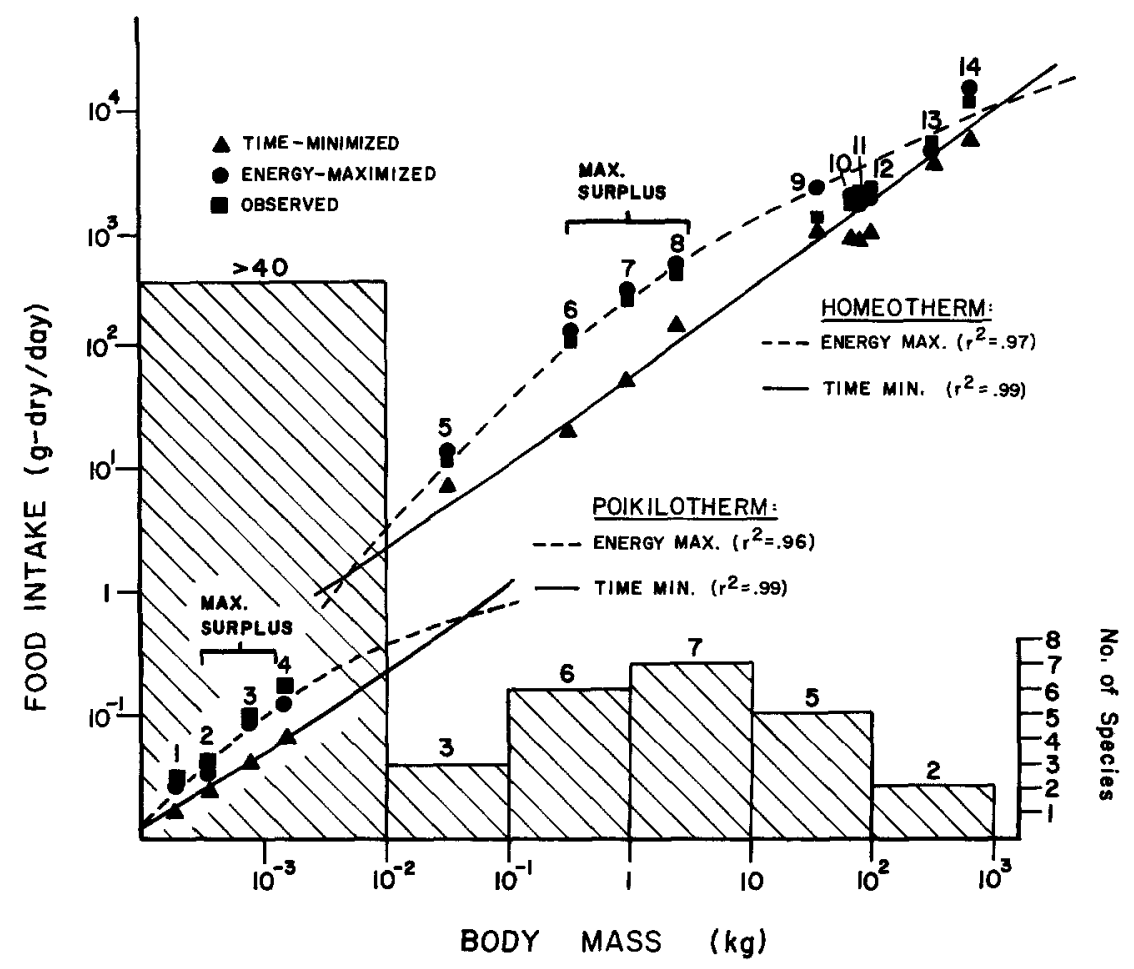

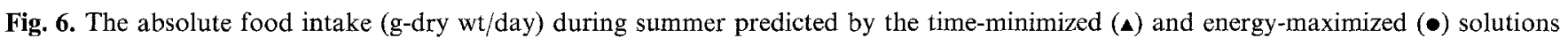
are plotted with the observed intake ( $\mathbf{m}$ : this study; Peden 1972; Short 1981; Alldredge et al. 1974; Wesley et al. 1973 ; Severson et al. 1968; Chappel and Hudson 1978b; Halls 1978; Hosley 1956; Hill 1956; Milne et al. 1976; Dean et al. 1980; Van Wormer 1969; Nelson and Leege 1982; Stelfox 1974; Armitage 1979) against body mass. The solid lines represent the curve fit to the predicted time-minimized intakes for endothermic and ectothermic herbivores; the dashed line is the curve fit to the predicted energy-maximized diets. The maximum difference between the dashed and solid curves represents body sizes which have more energy available to individuals and the intersection of the lines indicates either minimum or maximum body sizes for foraging (see text). The numbered points represent the species named in Fig. 3. The histogram presented illustrates the number of Bison Range herbivore species (right y-axis) of different body masses $\left(<10^{-2} \mathrm{~kg}\right.$ : Orthoptera; $10^{-2}-10^{-1} \mathrm{~kg}$ : Microtus pennsylvanicus, $M$. longicaudus, M. montanus; $10^{-1}-10^{0} \mathrm{~g}:$ Canachetes canadensis, Bonasa umbellus, Dendragapus obscurus, Thomomys talpoides, Spermophilus columbianus, Neotoma cineria; $10^{\circ}-10 \mathrm{~kg}:$ Sylvilagus nuttalli, Lepus townsendi, L. americanus, Erethizon dorsatum, Ondatra zibethica, Marmota flaviventris, Castor canadensis; 10-10 ${ }^{2} \mathrm{~kg}$ : Antilocapra americana, Oreamnos americanus, Ovis canadensis, Odocoileus hemionus, O. virginianus; $10^{2}-10^{3}:$ Cervus elaphus, Bison bison)

such as toxins. Also, this leads one to question the idea that monocots have coevolved in a mutualistic fashion with herbivores and are less defended while dicots are more defended (Owen and Wiegert 1976, 1981; Owen 1980; McNaughton $1979 \mathrm{a}, \mathrm{b}$ ).

The findings presented here are consistent with Feeny's (1976) and Rhoades and Cates' (1976) arguments that plants which are abundant and not patchily distributed in either space or time (monocots) will be heavily defended. This defense should be provided by quantitative defenses, which impact on most herbivores. Although little evidence exists for toxins in graminoids, an ultimate quantitative defense in plants is low nutrient or energy content which is the case for monocots. Plants that are not abundant and are very patchily distributed will be less well defended and their defenses will be qualitative, which impact on specific herbivores (dicots). Although it must be stressed that sweeping comparisons must be made with caution (Silvertown 1982), these results illustrate the need to examine plant defenses using a suite of herbivores in an environment and a range of factors that determine plant acceptability to the herbivore.

Community effects of foraging. Thus far in this analysis, we have examined the percentage of monocot and dicot comprising the diet, not absolute food intake. Figure 6 pres- ents the predicted intake of food per day for energy-maximizing and time-minimizing strategies which can be compared with the observed intake for captive individuals in this study or others reported in the literature. The limits imposed by the energy-maximizing and the time-minimizing food-intake values bound the intake values an herbivore can achieve and still survive and reproduce in the environment. Contrasting the above two intake levels with the observed intake, the energy-maximized intake is found to be slightly better correlated with the observed intake $\left(r^{2}=0.99\right.$, $n=14, P<0.001$, vs. $r^{2}=0.92$ for time minimization). This is consistent with the conclusion that herbivores are energy maximizers, though without the diet comparisons above it would be weak support.

Using absolute food intake values, we can make some predictions of community structure on the basis of trophic dynamics. If the time-minimizing intake is greater than the energy-maximizing intake (Fig. 6), then the herbivore cannot satisfy its energy demands and will not persist in the environment. The minimum sizes for herbivores that are still able to satisfy their energy demands (Fig. 6) are $10^{-5}-10^{-4} \mathrm{~kg}$ and $10^{-3}-10^{-2} \mathrm{~kg}$, for ectotherms and endotherms, respectively. As might be expected, the smallest ectotherms will be smaller than the smallest endotherms. This can be envisioned if we consider a similar ability to ingest energy for ectotherms and endotherms at a given 
small size which arises from their similar digestive capacity and feeding time constraints. Consequently, the ecotherms should be able to survive at lower body sizes because of their lower absolute energy requirements at a given size than those for endotherms.

The smallest chewing ectothermic herbivores, first instar grasshoppers, fall into the $10^{-5}$ to $10^{-4} \mathrm{~kg}$ size class at the Bison Range and the smallest endothermic herbivores, recently weaned microtines, approximately $8 \mathrm{~g}$, fall into the $10^{-3}-10^{-2} \mathrm{~kg}$ size class. Therefore, it appears that minimum herbivore sizes at the Bison Range may be consistent with the sizes set by foraging energetics.

A maximum size at which energy demands are not satisfied may also be found. For ectothermic herbivores the predicted maximum (approx. $50 \mathrm{~g}$ ) is much larger than the observed maximum (approx. $1.5 \mathrm{~g}$ ) indicating that foraging energetics may not explain the largest observed sizes. A maximum size, however, does emerge for endotherms at a size slightly greater than $10^{3} \mathrm{~kg}$ (Fig. 6), corresponding with the largest mammal at the Bison Range, a large bull bison at $1,250 \mathrm{~kg}$.

The maximum size for ectothermic herbivores may be set by considerations other than foraging, such as predation, the physiology of respiration, and climate. Competition with the smallest endothermic herbivores also may preclude larger ectotherms. The endotherms within these size ranges may be competitively superior as they appear to be able to acquire more energy in foraging relative to their requirements (greater deviation between time-minimized and energy-maximized lines in Fig. 6) than ectotherms. The cause of this observation is uncertain but it might arise from the endotherm's foraging constraints being less dependent upon climatic conditions (feeding time and digestive capacity are not temperature dependent).

If foraging also sets a maximum size for endothermic herbivores, we must question arguments that large mammalian herbivores went extinct at the end of the Pleistocene from human hunting (Martin 1973). Many of the extinct herbivorous species were larger than Bison bison and the above analysis indicates that larger herbivores are not energetically capable of surviving in this grassland which is one of the more productive regions in North America for herbivores. Therefore, the existence today of the larger extinct herbivores would be impossible; i.e., no niche space exists for them. Perhaps, the environment changed at the end of the Pleistocene by becoming more xeric (Hester 1967) which might have made the foraging energetics of the larger species untenable.

From Fig. 6, one can see that certain body sizes of herbivores can obtain relatively more energy above their requirements (energy obtained/energy requirement) than other herbivore sizes, i.e., they are more efficient. This ratio is measured as the distance between the energy-maximized and time-minimized intakes since Fig. 6 is plotted in a log-log fashion. Even though these body sizes are more efficient, this does not imply that they should be selected for over other body sizes in the environment, because different sizes of herbivores use different food resources and have different amounts of food available in the environment (Belovsky 1984a, 1986). Nonetheless, individuals of certain sizes will be more efficient in acquiring the food energy available to them. If food availability limits the population growth of the herbivores studied, then individuals of species with certain body sizes should be capable of acquiring more ener- gy relative to their requirements than species with other body sizes. This might result in a more rapid population growth for species of these body sizes and a greater ability to withstand more intense competition for food. An ability to withstand intense competition might be reflected as the ability of more species of these sizes to coexist together.

To test whether more species coexist at body sizes with greater foraging efficiency, the number of species in a body size range can be compared with the body size's energy intake relative to metabolic requirements (feeding efficiency). Also, small body sizes may have greater numbers of species because small size permits greater specialization on microhabitats which are unavailable to larger species (Hutchinson and MacArthur 1959), i.e., the environment is patchier for small species.

Using the data in Fig. 6, we find that body size is highly correlated with species number, if energy intake relative to metabolic requirements is held constant, (partial correlation coefficient; $r=0.98, P<0.001, n=14$ ); and energy intake relative to requirements is highly correlated to species number, if body size is held constant (partial correlation coefficient; $r=0.95, P<0.001, n=14$ ). Overall, these two variables explain $98 \%$ of the variance in species number, with body size accounting for $71 \%$ and energy intake relative to requirements accounting for an additional $27 \%$.

Although body size is more important, the combination of body size and feeding efficiency to explain species number may be the reason for observed log-normal distributions of species number vs. body size (Hutchinson and MacArthur 1959; Schoener and Janzen 1968; May 1979). This species abundance distribution might arise from three distinct regions of body size and abundance characteristics. Small to intermediate-sized herbivores may be able to take advantage of greater microhabitat specialization and their greater foraging efficiency to have the greatest abundance, leading to a peak in the body size-abundance curve. Very small herbivores only have the advantage of greater microhabitat specialization because they have a low feeding efficiency; and larger herbivores have neither advantage. This leads to a left tail (very small sizes) of the size-abundance curve that is higher than the right tail (very large sizes). Therefore, a curve approximating a log-normal distribution might be produced.

The above statements on species number only bear on competition within a body size class, i.e., competition between species that forage similarly. It does not pertain to competition between body size classes, since this depends upon how similar in feeding different size classes are. Belovsky $(1984$ a, 1986) has shown experimentally how competition for food can explain the population dynamics of herbivores that are not taxonomically closely-related or have very different body sizes.

The relationship between diet and body size presented above indicates that if food is the object of competition, the competition probably is most intense for energy-rich foods, since all the herbivores appear to be energy maximizers. Also, herbivores with certain body sizes are more likely to exhibit competition. Insects between $10^{-4}$ and $10^{-3} \mathrm{~kg}$ will compete most intensely with mammals between $10^{-1}$ and $10^{-2} \mathrm{~kg}$ for dicots, while insects between $10^{-3}$ and $10^{-2} \mathrm{~kg}$ will compete most intensely with mammals between $10^{2}$ and $10^{3} \mathrm{~kg}$ for monocots. The separation of herbivores into body mass classes, which tend to compete more intensely with each other, arises from their similarities 
in foraging constraints (i.e., feeding time-cropping rate, digestive capacity-food fill) examined above.

\section{Conclusion}

The optimal foraging analysis presented in this paper leads to a number of conclusions about herbivore foraging behavior. First, a single foraging model employing the same constraints (feeding time, digestive capacity and energy requirements), linear programming, appears to apply to all the herbivores studied. Second, all the herbivores in this study appear to be adopting a goal of energy maximization for all but very short periods (e.g., pronghorn males in the mating season). Third, the model solved for energy maximization appears to predict diets that follow a pattern with forager body size. Whether or not the same patterns occur in other herbivore communities must still be investigated, although similar patterns have been observed in a forest environment for a less diverse herbivore assemblage [moose, Alces alces; beaver, Castor canadensis and snowshoe hare, Lepus americanus (Belovsky 1978, 1984b, c)].

The observed foraging behavior patterns probably occur because herbivores have common anatomical and physiological processes constraining their diet choice (Belovsky 1984 d). These physiological processes are probably bodysize dependent, which leads to the relationship between diet choice and body size (Belovsky unpublished work).

Why do herbivores behave as energy maximizers? Perhaps seasonal food shortages arising from low abundance and quality, such as occur in winter, necessitate a long-term goal of energy maximization. Food shortages are not unique to herbivores living in temperate climates, for periods of low food abundance and quality also exist in tropical areas (Sinclair 1975). One must, however, bear in mind that the analysis has been restricted to generalist herbivores, those consuming a range of plant species, not specialists, such as many Lepidoptera, that feed on only one or several plant species (Belovsky 1984d).

The foraging strategy analysis provides more than just a means of estimating a species' diet and insights into its rationale for diet choice in the context of behavioral ecology. It enables us to examine community ecology problems. For example, the herbivore foraging analysis presented here indicates: 1) how 'plastic' different herbivore species are to changing environments through diet variability, 2) whether the largest and smallest body sizes for herbivores in an environment are set by foraging limitations, 3) whether or not certain herbivore body size classes are able to acquire more energy relative to their requirements, which should influence their population dynamics, if food limited, and 4) how foraging may bear on questions of the number of herbivore species in the environment and the potential for competition (Belovsky 1984a, 1986).

The underlying assumption for inferring community patterns from the foraging strategy model is that food limits the population dynamics of the herbivores. This immediately raises the question of the HSS hypothesis (Hairston et al. 1960; Slobodkin et al. 1967): that predators limit herbivore numbers. A review of the literature on generalist herbivore abundances and a set of experiments conducted by me (Belovsky 1984a, 1986) indicate that generalist herbivores appear to be food limited. This is not to say that predation does not influence herbivore population dynamics, but food availability and its apportionment between different species appears to be of principal importance (Belovsky 1984a).

Food limitation of herbivores, however, is by no means established and additional investigations on this matter must be undertaken. Whether differences should exist between specialist and generalist herbivores for food limitation is unknown and may be important for the relevance of HSS. Nonetheless, if this assumption continues to be borne out, the utility of foraging models for answering community structure questions can be seen and permits the linking of behavioral ecology with population biology (Belovsky 1986; Werner 1977).

Acknowledgments. I thank J.B. Slade and J. Marshall for their help in collecting the data, and the personnel of the National Bison Range for their help. I thank T.W. Schoener, S.L. Lima, A. Covich, M.E. Ritchie, and J.B. Slade for critically reading early drafts of this paper and supplying helpful comments. The work was supported by NSF grant DEB-78-02069 A01 to the author and T.W. Schoener, and grants to the author from Harvard Society of Fellows, Richmond Society, Harvard University, and The National Geographics Society.

\section{References}

Alldredge WA, Lipscomb JF, Whicker FW (1974) Forage intake rates of mule deer estimated with fallout cesium-137. J Wildl Manage 38:508-516

Allen EO (1968) Range use, foods, condition, and productivity of white-tailed deer in Montana. J Wildl Manage 32:130-141

Allo AA, Oh JH, Longhurst WM, Connolly GE (1973) VFA production in the digestive systems of deer and sheep. J Wildl Manage 37:202-211

Anderson AE, Snyder WA, Brown GW (1965) Stomach content analyses related to condition in mule deer, Guadalupe Mountains, New Mexico. J Wildl Manage 29:352-366

Anthony RG (1976) Influence of drought on diets and numbers of desert deer. J Wildl Manage 40:140-144

Anthony RG, Smith NS (1974) Comparison of rumen and fecal analysis to describe deer diets. J Wildl Manage 38:535-540

Arman P, Hopcraft D (1975) Nutritional studies on East African herbivores. I. Digestibilities of dry matter, crude fibre and crude protein in antelope, cattle and sheep. Brit J Nutr 33:255-261

Armitage KB (1979) Food selectivity by yellow-bellied marmots. J Mamm 60:628-629

Aumann GD (1965) Microtine abundance and soil sodium levels. J Mamm 46:594-604

Aumann GD, Emlen JT (1965) Relation of population density to sodium selection by microtine rodents. Nature 208:198-199

Bailey ED (1965) Seasonal changes in metabolic activity of nonhibernating woodchucks. Can J Zool 43:905-909

Bailey CG, Mukerji MK (1976) Consumption and utilization of various food plants by Melanoplus bivittatus (Say) and $M$. femur-rubrum (DeGeer) (Orthoptera: Acrididae). Can J Zool $54: 1044-1050$

Bailey CG, Mukerji MK (1977) Energy dynamics of Melanoplus bivittatus and $M$. femur-rubrum (Orthoptera: Acrididae) in a grassland ecosystem. Can Ent 109:605-614

Bakko EB (1977) Field water balance performance in prairie dogs (Cynomys leucurus and C. ludovicianus). Comp Biochem Physiol $56 \mathrm{~A}: 443-451$

Barmore WJ (1969) Pronghorn-mule deer range relationships on the northern Yellowstone winter range. In: Annual report, Office of Natural Science Studies, National Park Service $p$ 121-137

Bartmann RM, Alldredge AW, Neil PH (1982) Evaluation of winter food choices by tame mule deer. J Wild Manage 46:807-812

Beale DM, Smith AD (1970) Forage use, water consumption, and 
productivity of pronghorn antelope in western Utah. J Wildl Manage 34:570-582

Becker BW (1972) Competition between pronghorn and cattle. Biennial Antelope States Workshop 5:244 248

Bell RMV (1969) The use of the herb layer by grazing ungulates in the Serengeti National Park, Tanzania. PhD Dissertation, Manchester University, Manchester, England

Bell RMV (1971) A grazing ecosystem in the Serengeti. Sci Amer 224:86-93

Belovsky GE (1978) Diet optimization in a generalist herbivore: the moose. Theor Pop Biol 14:105-134

Belovsky GE (1981 a) Food plant selection by a generalist herbivore: the moose. Ecology 62:1020-1030

Belovsky GE (1981 b) Optimal activity times and habitat choice of moose. Oecologia (Berlin) 48:22-30

Belovsky GE (1981 c) A possible population response of moose to sodium availability. J Mamm 62:631-633

Belovsky GE (1984a) Moose and snowshoe hare competition and a mechanistic explanation from foraging theory. Oecologia (Berlin) $61: 150-159$

Belovsky GE (1984b) Snowshoe hare optimal foraging and its implications for population dynamics. Theor Pop Biol 25:235-264

Belovsky GE (1984c) Summer diet optimization by beaver. Am Midl Nat 111:209-222

Belovsky GE (1984d) Herbivore optimal foraging: new data and a comparison of three models. Am Nat 124:97-115

Belovsky GE (1986) Generalist herbivore foraging and its role in competitive interactions. Am Zool 26:51-69

Belovsky GE, Jordan PA (1978) The time-energy budget of a moose. Theor Pop Biol 14:76-104

Belovsky GE, Jordan PA (1981) Sodium dynamics and adaptations of a moose population. J Mamm 62:613-621

Belovsky GE, Slade JB (1986) The importance of body size and thermal environment in the time budgets of some grassland herbivores. Oecologia (Berlin) 70:53-62

Bernays EA, Chapman RF (1972) Meal size in nymphs of Locusta migratoria. Ent Exp Appl 15:399-410

Berwick SH (1968) Observations on the decline of the Rock Creek, Montana, population of bighorn sheep. Master's Thesis, University of Montana, Missoula, Montana

Blaxter KL (1962) The Energy Metabolism of Ruminants. Hutchinson, London

Blood DA (1967) Food habits of the Ashnola bighorn sheep herd. Can Field Nat $81: 23-24$

Boeker EL, Scott VE, Reynolds HG, Donaldson BA (1972) Seasonal food habits of mule deer in southwestern New Mexico. J Wildl Manage 36:56-63

Bookhout TA (1965) Feeding coactions between snowshoe hares and white-tailed deer in northern Michigan. Trans N Amer Wildl and Nat Resour Conf 30:321-335

Botkin DB, Jordan PA, Dominski AS, Lowendorf HS, Hutchinson GE (1973) Sodium dynamics in a northern ecosystem. Proc Nat Acad Sci 70:2745-2748

Bott E, Denton DA, Goding JR, Sabine JR (1964) Sodium deficiency and corticosteroid secretion in cattle. Nature 202:461-463

Brown ER (1961) The black-tailed deer of western Washington. Biology Bulletin No. 13. Washington Department of Game, Olympia

Brown JH (1981) Two decades of homage to Santa Rosalia: toward a general theory of diversity. Am Zool 21:877-888

Bryant CC, Kothman MM, Merrill LB (1979) Diets of sheep, angora goats, Spanish goats and white-tailed deer under excellent range conditions. J Range Manage 32:412-417

Buechner HK (1947) Range use of the pronghorned antelope in western Texas. Twelfth N Amer Wildl Conf 12:185-192

Buechner HK (1950) Life history, ecology, and range use of the pronghorn antelope in Trans-Pecos, Texas. Am Midl Nat 43:257-354

Buechner HK (1952) Winter range utilization by elk and mule deer in southeastern Washington. J Range Manage 5:76-80
Burt WH, Grossenheider RP (1964) A field guide to the mammals. Houghton Mifflin Co., Boston, Massachusetts

California Wildlife Investigations Laboratory (N.d) Report on special deer collection, 1961-1962, Rockport, Mendocino County, California. California Department of Fish and Game, Sacramento

Campling RC, Filer M, Balch CC (1961) Factors affecting the voluntary intake of food by cows 2 . The relationship between the voluntary intake of roughages, the amount of digesta in the reticulo-rumen, and the rate of disappearance of digesta from the alimentary tract. Brit J Nutr 15:531-540

Chamrad AD, Box TW (1968) Food habits of white-tailed deer in south Texas. J Range Manage 21:158-164

Chappel RW, Hudson RJ (1978a) Winter bioenergetics of Rocky Mountain bighorn sheep. Can J Zool 56:2388-2393

Chappel RW, Hudson RJ (1978 b) Energy cost of feeding in Rocky Mountain bighorn sheep. Acta Theriol 23, 21:359-363

Chappel RW, Hudson RJ (1980) Prediction of energy expenditures by Rocky Mountain bighorn sheep. Can J Zool 58:1908-1912

Church DC, Hines WH (1978) Ruminoreticular characteristics of elk. J Wildl Manage 42:654-659

Cliff EP (1939) Relationship between elk and mule deer in the Blue Mountains of Oregon. Fourth $\mathrm{N}$ Amer Wildl Conf 4:560-569

Cole GF (1969) The elk of Grand Teton and southern Yellowstone National Parks. Yellowstone Library and Museum Assoc.

Collins WB, Urness PJ (1983) Feeding behavior and habitat selection of mule deer and elk on northern Utah summer range. J Wild1 Manage 47:646-663

Collins WB, Urness PJ, Austin DD (1978) Elk diets and activities on different lodgepole pine habitat segments. J Wildl Manage 42:799-810

Constan KJ (1972) Winter foods and range use of three species of ungulates. J Wildl Manage 36:1068-1076

Couey FM (1946) Antelope foods in southeastern Montana. J Wild Manage 10:367

Cowan IMcT (1945) The ecological relationships of the food of the Columbian black-tailed deer (Odocoileus hemionus columbianus Richardson) in the coast forest region of southern Vancouver Island, British Columbia. Ecol Monogr 15:109-139

Cowan IMcT (1947) Range competition between mule deer, bighorn sheep, and elk in Jasper Park, Alberta. Twelfth N Amer Wildl Conf 12:223-227

Currie PO, Reichert DW, Malechek JC, Wallmo OC (1977) Forage selection comparisons for mule deer and cattle under managed Ponderosa pine. J Range Manage 30:352-356

Dadd RH (1960) Observations on the palatability and utilization of foods by locusts, with particular reference to the interpretation of performances in growth trials using synthetic diets. Ent Exp Appl 3:283-304

Dailey TV (1980) Diets of tame mountain goats and bighorn sheep in Colorado. Proc Biennial Symp Northern Wild Sheep and Goat Council, p 382

Davey PM (1954) Quantities of food eaten by the desert locust, Schistocerca gregaria Forsk in relation to growth. Bull Ent Res 45:539-551

Dean RE, Strickland MD, Newman JL, Thorne ET, Hepworth WG (1975) Reticulo-rumen characteristics of malnourished mule deer. J Wildl Manage 39:601-604

Dean RE, Thorne ET, Moore TD (1980) Passage rate of alfalfa through the digestive tract of elk. J Wildl Manage 44:272-273

DeNio RM (1938) Elk and deer foods and feeding habits. Third N Amer Wildl Conf 3:421-427

Denton DA (1956) The effect of $\mathrm{Na}^{+}$depletion on the $\mathrm{NA}^{+}: \mathrm{K}^{+}$ ratio of the parotid saliva of the sheep. J Physiol 131:516-525

Denton DA (1957) The study of sheep with permanent unilateral parotid fistulae. Quart J Exp Physiol 42:72-95

Denton DA (1965) Evolutionary aspects of the emergence of aldosterone secretion and salt appetite. Physiol Rev 45:245-295

Denton DA, Goding JR, MacDonald IR, Sabine R, Wright RD (1961) Adaptation of ruminant animals to variation of salt in- 
take. In: Salinity problems in the arid zones. Proc Teheran Symp, Paris pp 193-198

Deschamp JA, Urness PJ, Austin DD (1979) Summer diets of mule deer from lodgepole pine habitats. J Wildl Manage 43:154-161

Dirschl HJ (1963) Food habits of the pronghorn in Saskatchewan. J Wildl Manage 27:81-93

Dorn RD (1970) Moose and cattle food habits in southwest Montana. J Wild Manage 34:559-564

Drawe DL (1968) Mid-summer diet of deer on the Welder Wildlife Refuge. J Range Manage 21:164-166

Dusek GL (1975) Range relations of mule deer and cattle in prairie habitat. J Wildl Manage 39:605-616

Dyer MI, Bokhari UG (1976) Plant-animal interactions: studies of the effects of grasshopper grazing on blue grama grass. Ecology $57: 762-772$

Everitt JH, Drawe DL (1974) Spring food habits of white-tailed deer in the South Texas Plains. J Range Manage 27:15-20

Everitt JH, Gonzalez CL (1979) Botanical composition and nutrient content of fall and early winter diets of white-tailed deer in South Texas. Southwest Nat 24:297-310

Feeny P (1976) Plant apparency and chemical defense. Recent Advances in Phytochemistry 10:1-40

Ferrel CM, Leach HR (1949) Food habits of the pronghorn antelope of California. California Fish and Game. 36:21-26

Ferrel CM, Leach HR (1950a) Food habits of a California deer herd. California Fish and Game 36:235-240

Ferrel CM, Leach HR (1950b) The pronghorn antelope of California with special reference to food habits. California Fish and Game. 38:285-293

Free JC, Hansen RM, Sims PL (1970) Estimating dryweights of foodplants in feces of herbivores. J Range Manage 23:300-302

French CE, McEwen LC, Magruder ND, Ingram RH, Swift RW (1955) Nutritional requirements of white-tailed deer for growth and antler development. Bulletin 600. Pennsylvania Agricultural Experiment Station, University Park

Golley FB (1961) Energy values of ecological materials. Ecology 42:581-584

Gordon FA (1968) Range relationships of elk and cattle on elk winter range, Crow Creek, Montana. Job Completion Report, Project W-73-R-12, 13, 14, and W-98-R-R and 9. Montana Fish and Game Department, Helena

Greer KR, Kirsch JB, Yeager HW (1970) Seasonal food habits of the northern Yellowstone elk herds during 1957 and 1962-67 as determined from 793 rumen samples. Project W-83-R-12. Montana Fish and Game Department, Helena

Gwynne MD, Bell RMV (1968) Selection of grazing components by grazing ungulates in the Serengeti National Park. Nature (Lond) 220:390-393

Gyllenberg G (1970) Energy flow through a simple food chain of a meadow ecosystem in four years. Ann Zool Fenn $7: 283-289$

Hairston NG, Smith FE, Slobodkin LB (1960) Community structure, population control and competition. Am Nat 94:421-425

Halloran AF (1943) Management of deer and cattle on the Arkansas National Wildlife Refuge. Texas J Wildl Manage 7:203-216

Halls LK (1978) White-tailed deer. Schmidt JL, Gilbert DL (eds), Big game of North America: ecology and management. Stackpole Books, Harrisburg, Pennsylvania pp 43-66

Hanley TA (1980) Nutritional constraints on food and habitat selection by sympatric ungulates. PhD Dissertation, University of Washington, Seattle, Washington

Hanley TA, Hanley KA (1982) Food resource partitioning by sympatric ungulates on Great Basin rangeland. J Range Manage $35: 152-158$

Hansen RM, Clark RC (1977) Foods of elk and other ungulates at low elevations in northwestern Colorado. J Wildl Manage $41: 76-80$

Hansen RM, Dearden BL (1975) Winter foods of mule deer in Piceance Basin, Colorado. J Range Manage 28:298-300

Harper JA (1962) Daytime feeding habits of Roosevelt elk on Boyes Prairie, California. J Wildl Manage 26:97-100
Harper JA, Harn JH, Bentley WW, Yocom CF (1967) The status and ecology of the Roosevelt elk in California. Wildl Monogr No 16

Hawley AWL, Peden DG, Reynolds HW, Stricklin WR (1981) Bison and cattle digestion of forages from the Slave River lowlands, Northwest Territories, Canada. J Range Manage 34:126-130

Hemmingsen AM (1960) Energy metabolism as related to body size and respiratory surfaces and its evolution. Rep Steno Mem Hosp Nord Insulin Lab 9:3-110

Hester JJ (1967) The agency of man in animal extinctions. In: Martin PS, Wright Jr, HE, Frye DG (eds), Pleistocene extinctions: the search for a cause. Yale Univ Press, New Haven pp 169-192

Hill RR (1956) Forage, food habits, and range management of the mule deer. In: Taylor WP (ed), The deer of North America: their history and management. Stackpole Books, Harrisburg, Pennsylvania pp 393-414

Hill R, Harris D (1943) Food preferences of Black Hills deer. J Wildl Manage 7:233-235

Hixon MA (1982) Energy maximizers and time minimizers: theory and reality. Am Nat 119:596-599

Hlavachick BD (1968) Foods of Kansas antelopes related to choice of stocking sites. J Wildl Manage 32:399-401

Hobbs NT, Baker DL, Ellis JE, Swift DM (1981) Composition and quality of elk winter diets in Colorado. J Wildl Manage 45:156-171

Hobbs NT, Baker DL, Gill RB (1983) Comparative nutritional ecology of montane ungulates during winter. J Wildl Manage 47:1-16

Hosley NW (1956) Management of white-tailed deer in its environment. In: Taylor WP (ed), The deer of North America: their history and management. Stackpole Books, Harrisburg, Pennsylvania pp $187-259$

Hubbard RE, Hansen RM (1976) Diets of wild horses, cattle, and mule deer in the Piceance Basin, Colorado. J Range Manage $29: 389-392$

Hudson RJ, Nietfeld MT (1985) Effect of forage depletion on the feeding rate of wapiti. J Range Manage 38:80-82

Hungerford CR (1970) Response of Kaibab deer to management of summer range. J Wildl Manage 34:852-862

Husain MA, Mathur CB, Roonwaal ML (1946) Studies on Schistocerca gregaria. XIII. Food and feeding habits of the desert locust. Indian J Ent 8:141-163

Hutchinson GE, Deevey ES (1949) Ecological studies on populations. Surv Biol Progr 1:325-359

Hutchinson GE, MacArthur RH (1959) On the theoretical significance of aggressive neglect in interspecific competition. Am Nat 93:133-134

Jameson EW, Jr (1947) Natural history of the prairie vole. Univ Kansas Publ, Mus Nat His 1:125-151

Jarman PJ (1972) The use of drinking sites, wallows and salt licks by herbivores in the flooded Zambezi Valley. E Afr Wild $\mathbf{J}$ 10:193-209

Joern A (1979) Feeding patterns in grasshoppers (Orthopetera: Acrididae): factors influencing diet specialization. Oecologia (Berlin) 38:325-347

Johnson MK (1979) Foods of primary consumers on cold desert shrubsteppe of southcentral Idaho. J Range Manage 32:365-368

Johnson MK. Hansen RM (1979) Foods of cottontails and woodrats in south-central Idaho. J Mamm 60:213-215

Jordan PA, Botkin DB, Dominski AS, Lowendorf HS, Belovsky GE (1973) The dilemma of sodium for moose of Isle Royale. Trans N Amer Moose Workshop 9:13-42

Karasov WH (1981) Daily energy expenditure and the cost of activity in a free-living mammal. Oecologia (Berlin) 51:253-259

Keller GL (1975) Seasonal food habits of desert mule deer (Odocoileus hemionus crooki) on a specific mule deer-cattle range in Pecos County, Texas. Master's Thesis, Sul Ross State University, Alpine, Texas 
Kimmins JP (1970) Cyclic fluctuations in herbivore populations in northern ecosystems: a general hypothesis. Unpubl PhD dissertation, Yale University, New Haven, Connecticut

Kitchen DW (1974) Social behavior and ecology of the pronghorn. Wildl Monogr No 38

Klebenow DA (1965) A montane forest winter deer habitat in western Montana. J Wildl Manage 29:27-33

Kleiber M (1961) The fire of life. John Wiley, New York

Klein DR (1962) Rumen contents analysis as an index to range quality. Trans N Amer Wildl and Nat Resour Conf 27:150-164

Klein DR. Schønheyder F (1970) Variation in ruminal nitrogen levels among some cervidae. Can J Zool 48:1437-1442

Korschgen LJ, Porath WR, Torgerson O (1980) Spring and summer foods of deer in the Missouri Ozarks. J Wildl Manage 44:89-97

Kostelecka-Myrcha A, Myrcha A (1964) The rate of passage of foodstuffs through the alimentary tracts of certain Microtidae under laboratory conditions. Acta Theriol 9:37-52

Krausman PR (1978) Forage relationships between two deer species in Big Bend National Park, Texas. J Wildl Manage 42:101-107

Krebs JR, Davies NB (1978) Behavioural ecology: an evolutionary approach. Sinauer Associates, Inc. Sunderland, Massachusetts

Kufeld RC (1973) Foods eaten by Rocky Mountain elk. J Range Manage 26:106-113

Kufeld RC, Wallmo OC, Feddema C (1973) Foods of the Rocky Mountain mule deer. U.S. Department of Agriculture, Forest Service Research Paper RM-111

Lauer JL, Peek JM (1976) Big game-livestock relationships on the bighorn sheep winter range, East Fork Salmon River, Idaho. Forest, Wildl and Range Exp Sta Bull No 12, University of Idaho

Leach HR (1956) Food habits of the Great Basin deer herds of California. California Fish and Game 42:243-308

Leach HR, Hiehle JL (1957) Food habits of the Tehama deer herd. California Fish and Game 43:161-178

Lee C, Horvath DJ (1969) Management of meadow vole (Microtus pennsylvanicus) (Abstr.) J Anim Sci 27:1517

Leopold AS, Riney T, McCain R, Tevis L Jr (1951) The Jawbone deer herd. California Fish and Game, Bull No 4, Sacramento

Lovaas AL (1958) Mule deer food habits and range use, Little Belt Mountains, Montana. J Wildl Manage 22:275-283

MacCracken JG, Hansen RM (1981) Diets of domestic sheep and other large herbivores in southcentral Colorado. J Range Manage $34: 242-243$

Mackie RJ (1970) Range ecology and relations of mule deer, elk, and cattle in the Missouri River Breaks, Montana. Wildl Monogr No 20

Maloiy GMO, Kay RNB (1971) A comparison of digestion in red deer and sheep under controlled conditions. Quart J Exp Physiol 56:257-266

Martin PS (1973) The discovery of America. Science 179:969-974

Martinka CJ (1968) Habitat relationships of white-tailed and mule deer in northern Montana. J Wild I Manage 32:558-565

Mason E (1952) Food habits and measurements of Hart Mountain antelope. J Wildl Manage 16:387-389

Mautz WW, Petrides GA (1971) Food passage rate in the whitetailed deer. J Wildl Manage 35:723-731

May RM (1979) The structure and dynamics of ecological communities. In: Anderson RM, Turner BD, Taylor LR (eds), Symp Brit Ecol Soc 20, Population Dynamics. Blackwell Scientific Publications, Oxford pp 385-407

McCollough SA, Cooperrider AY, Bailey JA (1980) Impact of cattle grazing on bighorn sheep habitat at Trickle Mountain, Colorado. Proc Biennial Symp Northern Wild Sheep and Goat Council pp 42-58

McCulloch CY (1969) Some effects of wildfire on deer habitat in pinyon-juniper woodland. J Wildl Manage 33:778-784

McCulloch CY (1973) Deer nutrition in Arizona chaparral and desert habitats. Special Report No. 3. Research Division, Arizona Game and Fish Department
McCulloch CY (1978) Statewide deer food preferences. P-R Project WP4, J15. Arizona Game and Fish Department, Phoenix

McCullough YB (1980) Niche separation of seven North American ungulates on the National Bison Range, Montana. $\mathrm{PhD}$ Dissertation, University of Michigan, Ann Arbor, Michigan.

McMahan CA (1964) Comparative food habits of deer and three classes of livestock. J Wildl Manage 28:798-808

McNaughton SJ (1979a) Grazing as an optimization process: grassungulate relationships in the Serengeti. Am Nat 113:691-703

McNaughton SJ (1979b) Grassland-herbivore dynamics. In: Sinclair ARE, Norton-Griffiths $M$ (eds), Serengeti: dynamics of an ecosystem. The University of Chicago Press, Chicago pp 46-81

Meagher MM (1973) The bison of Yellowstone National Park. National Park Serv Monogr No 1

Milne JA, MacRae JC, Spence AM, Wilson S (1976) Intake and digestion of hill-land vegetation by the red deer and the sheep. Nature 263:763-764

Mitchell GJ, Smoliak S (1971) Pronghorn antelope range characteristics and food habits in Alberta. J Wildl Manage 35:238250

Moen AN (1973) Wildlife ecology: an analytical approach. WH Freeman and $\mathrm{Co}$, San Francisco

Morris MS, Schwartz JE (1957) Mule deer and elk food habits on the National Bison Range. J Wildl Manage 21:189-193

Mulkern GB, Pruess KP, Knutson K, Hagen AF, Campbell JB, Lambley JD (1969) Food habits and preferences of grassland grasshoppers of the North Central Great Plains. N Dak Agr Exp Sta Bull No 481

Murie OJ (1951) The elk of North America. The Stackpole Co, Harrisburg, Pennsylvania

Murphy DA, Coates JA (1966) Effects of dietary protein on deer. Trans N Amer Wildl and Nat Res Conf 31:129-139

Nagy JG, Regelin WL (1975) Comparison of three deer species. J Wild1 Manage 39:621-624

Neff DJ (1974) Forage preference of trained mule deer on the Beaver Creek watersheds. Arizona Game and Fish Department Special Report No. 4

Nellis CH, Ross RL (1969) Changes in mule deer food habits associated with herd reduction. J Wildl Manage 33:191-195

Nelson JR, Burnell DO (1975) Elk-cattle competition in central Washington. In: Range Multiple Use Mangement. University of Idaho, Moscow

Nelson JR, Leege TA (1982) Nutritional requirements and food habits. In: Thomas JW, Toweill DE (eds), Elk of North America: ecology and management. Stackpole Books, Harrisburg, Pennsylvania pp 323-368

O'Gara BW (1970) Derivation of whole weight for the pronghorn. J Wildl Manage 34:470-472

O'Gara BW, Greer KR (1970) Food habits in relation to physical condition in two populations of pronghorns. Proc Antelope States Workshop 4:131-139

Oldemeyer JL, Barmore WJ, Gilbert DL (1971) Winter ecology of bighorn sheep in Yellowstone National Park. J Wildl Manage 35:257-269

Owen DF (1980) How plants may benefit from the animals that eat them. Oikos 35:230-235

Owen DF, Wiegert RG (1976) Do consumers maximize plant fitness? Oikos 27:488-492

Owen DF, Wiegert RG (1981) Mutualism between grasses and grazers: an evolutionary hypothesis. Oikos 36:376-378

Owen-Smith N, Novellie P (1982) What should a clever ungulate eat? Am Nat 119:151-178

Packard GC (1968) Oxygen consumption of Microtus montanus in relation to ambient temperature. J Mamm 49:215-220

Peden DG (1971) Preliminary activities and results in bison research on the Pawnee site. IBP Grassland Biome Tech Rep No 121. $\mathrm{p} 6$

Peden DG (1972) The trophic relations of Bison bison to the shortgrass plains. PhD Dissertation, Colorado State University, Fort Collins, Colorado 
Peden DG (1976) Botanical composition of bison diets on shortgrass plains. Am Midl Nat 96:225-229

Peden DG, Van Dyne GM, Rice RW, Hansen RM (1974) The trophic ecology of Bison bison L. on shortgrass plains. J Appl Ecol 11:489-497

Pickford GD, Reid EH (1943) Competition of elk and domestic livestock for summer range forage. J Wildl Manage 7:328-332

Prins RA, Geilan MJH (1971) Rumen characteristics of red deer, fallow deer and roe deer. J Wildl Manage 35:673-680

Pyke GH, Pulliam HR, Charnov EL (1977) Optimal foraging: a selective review of theory and tests. Quart Rev Biol 55:137-154

Rapport DJ, Turner JE (1975) Feeding rates and population growth. Ecology 56:942-949

Rapport DJ, Turner JE (1977) Economic models in ecology. Science 195:367-373

Reichle DE (1968) Relation of body size to food intake, oxygen consumption and trace element metabolism in forest floor arthropods. Ecology 49:538-542

Reynolds RW, Hansen RM, Peden DG (1978) Diets of the Slave River lowland bison herd, Northwest Territories, Canada. J Wildl Manage 42:581-590

Rhoades DF, Cates RG (1976) Toward a general theory of plant antiherbivore chemistry. Recent Advances in Phytochemistry $10: 168-213$

Richmond RJ, Hudson RJ, Christopherson RJ (1977) Comparison of forage intake and digestibility by American bison, Yak and cattle. Acta Theriol 22:225-230

Schaefer AL, Young BA, Chimwano AM (1978) Ration digestion and retention times of digesta in domestic cattle (Bos taurus), American bison (Bison bison), and Tibetan yak (Bos grunniens). Can J Zool 56:2355-2358

Schoener TW (1969) Models of optimal size for solitary predators. Am Nat 103:277-313

Schoener TW (1971) Theory of feeding strategies. Ann Rev Ecol Syst 2:369-403

Schoener TW (1983) Simple models of optimal feeding-territory size: a reconciliation. Am Nat 121:608-629

Schoener TW, Janzen DH (1968) Notes on environmental determinants of tropical versus temperate insect size patterns. Am Nat 102:207-224

Schoonveld GG, Nagy JG, Bailey JA (1974) Capability of mule deer to utilize fibrous alfalfa diets. J Wildl Manage 38:823-829

Schwartz CC, Nagy JG (1976) Pronghorn diets relative to forage availability in Northeastern Colorado. J Wildl Manage 40:469.478

Schwartz CC, Nagy JG, Price RW (1977) Pronghorn dietary quality relative to forage availability and other ruminants in Colorado. J Wildl Manage $41: 161-168$

Scoggins BA, et al. (1970) Physiological and morphological responses of mammals to changes in their sodium status. Mem Soc Endocrinol 18:577-600

Seegmiller RF, Ohmart RD (1981) Ecological relationships of feral burros and desert bighorn sheep. Wildl Monogr No 78

Severson KE, May M (1967) Food preferences of antelope and domestic sheep in Wyoming's Red Desert. J Range Manage 19:21-25

Severson K, May M, Hepworth W (1968) Food preferences, carrying capacities, and forage competition between antelope and domestic sheep in Wyoming's Red Desert. University of Wyoming Agricultural Experiment Station Science Monograph 10

Sexson ML, Choate JR, Nicholson RA (1981) Diet of pronghorn in western Kansas. J Range Manage 34:489-493

Shank CC (1982) Age-sex differences in the diets of wintering Rocky Mountain bighorn sheep. Ecology 63:627-633

Short HL (1963) Rumen fermentations and energy relationships in white-tailed deer. J Wildl Manage 27:184-194

Short HL (1964) Postnatal stomach development of white-tailed deer. J Wild I Manage 28:445-458

Short HL (1977) Food habits of mule deer in a semi-desert grassshrub habitat. J Range Manage 30:206-209

Short HL (1981) Nutrition and metabolism. In: Wallmo OC (ed),
Mule and black-tailed deer of North America. University of Nebraska Press, Lincoln pp 99-128

Short HL, Medin DE, Anderson AE (1965) Ruminoreticular characteristics of mule deer. J Mamm 46:196-199

Short HL, Medin DE, Anderson AE (1966) Seasonal variations in volatile fatty acids in the rumen of mule deer. J Wildl Manage $30: 466-470$

Short HL, Remmenga EE, Boyd CE (1969) Variations in ruminoreticular contents of white-tailed deer. J Wild Manage 33:187-191

Silver H, Holter JB, Colovos NF, Hayes HH (1971) Effect of falling temperatures on heat production in fasting white-tailed deer. J Wildl Manage 35:37-46

Silvertown JW (1982) No evolved mutualism between grasses and grazers. Oikos 38:253-259

Sinclair ARE (1975) The resource limitation of trophic levels in tropical grassland ecosystems. J Anim Ecol 44:497-520

Slobodkin LB, Smith FE, Hairston NG (1967) Regulation in terrestrial ecosystems, and the implied balance of nature. Am Nat $101: 109-124$

Smith AD (1965) Determining common use grazing capacities by application of the key species concept. J Range Manage 18:196-201

Smith AD, Shandruk LJ (1979) Comparison of fecal, rumen and utilization methods for ascertaining pronghorn diets. $J$ Range Manage 32:275-279

Smith DS (1959) Utilization of food plants by the migratory grasshopper, Melanoplus bilituratus (Walker) (Orthoptera: Acrididae), with some observations on the nutritional value of the plants. Ann Ent Soc Am 52:674-680

Smith JG (1952) Food habits of mule deer in Utah. J Wild1 Manage $16: 148-155$

Smith JG, Julander O (1953) Deer and sheep competition in Utah. J Wildl Manage 17:101-112

Smith MA, Malechek JC, Fulgham KO (1979) Forage selection by mule deer on winter range grazed by sheep in spring. J Range Manage 32:40-45

Snedecor GW, Cochran WG (1967) Statistical methods. 6th ed. Iowa State Univ Press, Ames, Iowa

Spalinger DE (1980) Mule deer habitat evaluation based upon nutritional modeling. PhD Dissertation, University of Nevada, Reno, Nevada

Sparks DR, Malechek JC (1968) Estimating percentage dry weight in diets using a microscopic technique. J Range Manage $21: 264-265$

Staines BW (1976) Experiments with rumen-cannulated red deer to evaluate rumen analyses. J Wildl Manage 40:371-373

Stelfox JG (1974) Browse production and utilization during 17 years of regeneration in a white spruce forest. Trans $N$ Amer Moose Conf and Workshop, Duluth, Minn 10:135-144

Stevens DR (1966) Range relationships of elk and livestock, Crow Creek drainage, Montana. J Wildl Manage 30:349-363

Stevens DR (1974) Rocky Mountain elk - Shiras moose range relationships. Le Naturaliste Canadien 101:505-516

Stormer FA, Bauer WA (1980) Summer forage use by tame deer in northern Michigan. J Wildl Manage 44:98-106

Storr GM (1963) Estimation of dry-matter intake in wild herbivores. Nature 197:307-308

Strum JE (1972) Introduction to linear programming. Holden-Day, San Francisco

Taber RD, Dasmann RF (1958) The black-tailed deer of the chaparral: its life history and management in the North Coast Range of California. Game Bulletin No. 8, California Department of Fish and Game, Sacramento

Taylor ER (1972) Food habits and feeding behavior of pronghorn antelope in the Red Desert of Wyoming. Biennial Antelope States Workshop. 5:211-219

Telfer ES (1967) Comparison of a deer yard and a moose yard in Nova Scotia. Can J Zool 45:485 490

Telfer ES (1972) Forage yield and browse utilization on logged areas in New Brunswick. Can J For Res 2:346-350 
Terry RA, Tilley JMA (1964) The digestibility of the leaves and stems of perennial ryegrass, cocksfoot, timothy, tall fescue, lucerne, and sainfoin, as measured by an in vitro procedure. J Brit Grassld Soc 19:363-372

Todd JW (1975) Foods of Rocky Mountain bighorn sheep in southern Colorado. J Wildl Manage 39:108-111

Travis J (1982) A method for the statistical analysis of time-energy budgets. Ecology 63:19-25

Ueckert DN (1968) Seasonal dry weight composition in grasshopper diets on Colorado herbland. Annals Ent Soc Amer $61: 1539-1544$

Ueckert DN, Hansen RM, Terwilliger C, Jr (1972) Influence of plant frequency and certain morphological variations on diets of rangeland grasshoppers. J Range Manage 25:61-65

Urness PJ (1981) Food habits and nutrition. In: Wallmo OC (ed), Mule and black-tailed deer of North America. University of Nebraska Press, Lincoln pp 347-365

Uzzell PB (1958) Deer food habits study: Trans-Pecos game management survey. P-R Project W-57-R, Job 7. Texas Game and Fish Commission, Austin,

Van Wormer J (1969) The world of the American elk. JB Lippicott, New York

Wallmo OC (ed) (1981) Mule and Black-Tailed Deer of North America. University of Nebraska Press, Lincoln

Wallmo OC, Regelin WL (1981) Food habits and nutrition. In: OC Wallmo (ed), Mule and black-tailed deer of North America. University of Nebraska Press, Lincoln pp 387-398

Wallmo OC, Gill RB, Carpenter LH, Reichert DW (1973) Accuracy of field estimates of deer food habits. J Wild Manage 37:556-562

Weeks HP, Jr, Kirkpatrick CM (1976) Adaptations of white-tailed deer to naturally occurring sodium deficiencies. J Wild Manage 40:610-625

Weir JS (1972) Spatial distribution of elephants in an African national park in relation to environmental sodium. Oikos $23: 1-13$
Weir JS (1973) Exploitation of water soluble soil sodium by elephants in Murchison Falls National Park, Uganda. E Afr Wildl J $11: 1-7$

Werner EE (1977) Species packing and niche complementarity in three sunfishes. Am Nat 111:553-578

Wesley DE, Knox KL, Nagy JG (1970) Energy flux and water kinetics in young pronghorn antelope. J Wildl Manage 34:908-912

Wesley DE, Knox KL, Nagy JG (1973) Energy metabolism of pronghorn antelopes. J Wildl Manage 37:563-573

Wickstrom ML, Robbins CT, Hanley TA, Spalinger DE, Parish SM (1984) Food intake and foraging energetics of elk and mule deer. $J$ Wildl Manage 48:1285-1301

Wiegert RG (1961) Respiratory energy loss and activity patterns in the meadow vole, Microtus pennsylvanicus pennsylvanicus. Ecology 42:245-253

Wilkins BT (1957) Range use, food habits, and agricultural relationships of the mule deer, Bridger Mountains, Montana. J Wild Manage 21:159-169

Willms W, McLean A (1978) Spring forage selection by tame mule deer on big sagebrush range, British Columbia. J Range Manage $31: 192-199$

Willms W, McLean A, Tucker R, Ritcey R (1979) Interactions between mule deer and cattle on big sagebrush range in British Columbia. J Range Manage 32:299-304

Willms W, Bailey AW, McLean A (1980) Effect of burning or clipping Agropyron spicatum in the autumn on the spring foraging behaviour of mule deer and cattle. J Appl Ecol 17:69-84

Zimmerman EG (1965) A comparison of habitat and food of two species of Microtus. J Mamm 46:605-612

Received December 1, 1985
Note added in proof. Fig. $2 b$. The energy-maximized diet should appear at the intersection of the $x$-axis (Monocot Intake) and the Digestive Capacity contraint $(S)$. Also, the confidence region represents $\pm 1 \mathrm{SE}$, not $95 \%$ confidence, for bison. 